Government Debt and Growth: The Role of Liquidity

Mathieu Grobéty

SNB Working Papers

13/2017 


\section{DISCLAIMER}

The views expressed in this paper are those of the author(s) and do not necessarily represent those of the Swiss National Bank. Working Papers describe research in progress. Their aim is to elicit comments and to further debate.

\section{COPYRIGHT $\odot$}

The Swiss National Bank (SNB) respects all third-party rights, in particular rights relating to works protected by copyright (information or data, wordings and depictions, to the extent that these are of an individual character).

SNB publications containing a reference to a copyright (@) Swiss National Bank/SNB, Zurich/year, or similar) may, under copyright law, only be used (reproduced, used via the internet, etc.) for non-commercial purposes and provided that the source is mentioned. Their use for commercial purposes is only permitted with the prior express consent of the SNB.

General information and data published without reference to a copyright may be used without mentioning the source. To the extent that the information and data clearly derive from outside sources, the users of such information and data are obliged to respect any existing copyrights and to obtain the right of use from the relevant outside source themselves.

\section{LIMITATION OF LIABILITY}

The SNB accepts no responsibility for any information it provides. Under no circumstances will it accept any liability for losses or damage which may result from the use of such information. This limitation of liability applies, in particular, to the topicality, accuracy, validity and availability of the information.

ISSN 1660-7716 (printed version)

ISSN 1660-7724 (online version)

(c) 2017 by Swiss National Bank, Börsenstrasse 15,

P.O. Box, $\mathrm{CH}-8022$ Zurich 


\title{
Government Debt and Growth: The Role of Liquidity*
}

\author{
Mathieu Grobéty ${ }^{\dagger}$ \\ Swiss National Bank
}

This draft: August 2017

First draft: May 2012

\begin{abstract}
How does government debt affect long-run economic growth? A prominent strand of theoretical literature suggests that government debt has a negative effect on growth. Another strand argues that government debt can foster growth by enhancing the supply of liquid assets or collateral. We empirically investigate the liquidity channel of government debt and apply the difference-in-differences methodology of Rajan and Zingales (1998) on a sample of 28 manufacturing industries across 39 developing and developed countries. We provide evidence that industries with greater liquidity needs tend to grow disproportionately faster in countries with higher levels of government debt. The positive liquidity effect of government debt on industry growth stems from domestic debt, not external debt. We perform a battery of robustness checks and show that our results are robust to using instrumental variables and controlling for many competing channels.
\end{abstract}

JEL classification : H63, D92, O16, G21

Keywords: Government Debt, Growth, Liquidity, Non-linearity

${ }^{*}$ I would like to thank Marnix Amand, Philippe Bacchetta, Kenza Benhima, Nicolas Cuche-Curti, Chiara Forlati, Alain Gabler, Carlos Lenz, Alberto Martin, Nikola Mirkov, Romain Rancière, Romain Restout and Mathias Thoenig for their valuable comments and suggestions. I also thank seminar participants at the Swiss National Bank, the University of Lausanne, the Second Sinergia Common Workshop (EPFL), the T2M Conference 2014 (Lausanne), the KOF research workshop and the BIS-SNB workshop. All remaining errors are mine. Conflicts of interest: none. The views, opinions, findings, conclusions and recommendations expressed in this paper are strictly those of the author and do not necessarily reflect the views of the Swiss National Bank (SNB). The SNB takes no responsibility for any errors or omissions or for the accuracy of the information included in this paper.

${ }^{\dagger}$ Mathieu Grobéty, Swiss National Bank, Börsenstrasse 15, P.O. Box, CH-8022 Zurich, Switzerland. Tel.: +41-58631-38-92; fax: +41-58-631-31-75; E-mail: mathieu.grobety@snb.ch 


\section{Introduction}

How does government debt affect long-run economic growth? Theoretical literature on the debtgrowth relationship identifies several potential channels. The standard channel rests on the crowdingout effect of government debt on private investment. In both neoclassical and endogenous growth models, the crowding-out effect hinders capital accumulation and reduces long-run growth (Diamond, 1965; Saint-Paul, 1992). In addition, government debt can have detrimental effects on growth through higher distortionary taxes (Barro, 1979; Dotsey, 1994), higher private borrowing costs triggered by sovereign default risk (Corsetti et al., 2013), and greater uncertainty or expectation of future financial repression (Cochrane, 2011). Another strand of literature argues that government debt can foster growth by enhancing the supply of liquid assets or collateral. This is the liquidity channel through which government debt facilitates private investment by relaxing financial constraints (Woodford, 1990; Holmström and Tirole, 1998) and thereby can be growth-enhancing.

This paper aims to investigate the empirical relevance of the liquidity channel of government debt using the difference-in-differences methodology developed by Rajan and Zingales (1998) (henceforth RZ). Controlling for country and industry fixed effects, we regress long-run industry growth in a cross-section of countries on an interaction term between sectoral liquidity needs based on U.S. data and the government debt-to-GDP ratio. To the best of our knowledge, we are the first to conduct a cross-country/cross-industry analysis to examine the long-run relationship between government debt and growth. Existing empirical literature relies on a cross-country analysis (e.g. Reinhart and Rogoff, 2010a,b; Kumar and Woo, 2010; Cecchetti et al., 2011; Checherita-Westphal and Rother, 2012).

The RZ methodology has three primary advantages over a cross-country analysis. First, it is less prone to the problem of reverse causality. The debt-growth relationship may be driven by high levels of government debt generated during episodes of slow economic growth (Easterly, 2001; Reinhart et al., 2012). This potential endogeneity problem leading to a downward bias in OLS cross-country regressions has been addressed but not fully resolved (Reinhart et al., 2012; Panizza and Presbitero, 2013, 2014). In contrast, the RZ methodology mitigates the scope for reverse causality because the dependent variable is measured at the sectoral level. Because the size of an industry is small relative to the size of the economy, feedback from industry growth to government debt becomes less of an issue. Second, fixed effects take care of a wide range of omitted variables. Using the RZ methodology, we only need to control for channels that may be correlated with the liquidity channel. In the cross-country framework, the set of potential omitted variables appears to be larger. Any country-specific growth determinants correlated with government debt need to be included as control variables. Third, the difference-in-differences methodology of RZ provides a direct test of causality. Industries with low liquidity needs represent the control group for industries with high liquidity needs, while the treatment corresponds to an increase in government debt across countries. We clearly establish the direction of causality by focusing on a specific channel through which government debt affects economic growth. Cross-country outcomes only show correlation and cannot be interpreted as evidence for a causal effect running from government debt to economic 
growth (Panizza and Presbitero, 2014).

The RZ methodology has a major drawback compared to cross-country regressions: the countrywide effect of government debt on growth is subsumed in the country fixed effects and cannot be identified. A cross-industry analysis seeks to estimate the aggregate magnitude of the growth effect of government debt. In contrast, our cross-country/cross-industry analysis allows us to identity a difference-in-differences effect, namely, how much faster industries with high liquidity needs grow relative to those with low liquidity needs after an increase in the government debt level.

Using a sample of 28 manufacturing industries across 39 developing and developed countries, we provide empirical evidence in favor of the liquidity channel of government debt. To do so, we use the industry-specific measure of liquidity needs from Raddatz (2006) computed as the ratio of inventories to sales using U.S. firm-level data. Data for the level and composition of government debt are obtained from Panizza (2008). We find that industries with greater liquidity needs tend to grow disproportionately faster in countries with higher levels of government debt (relative to GDP). The positive liquidity effect of government debt on industry growth stems from domestic debt, not external debt. Industries with high liquidity needs do not grow significantly faster in countries with more external government debt. Then, we assess the economic magnitude of the liquidity channel and find that it is quantitatively relevant. First, our estimation results indicate that an industry with high liquidity needs (ranked at the 75th percentile) grows annually in real terms almost 0.5 percentage points faster than an industry with low liquidity needs (ranked at the 25th percentile) after an increase of the domestic government debt-to-GDP ratio by 10 percentage points. This corresponds to about one quarter of the average annual industry growth in our sample (equal to $1.86 \%$ ). Second, we show that the liquidity channel explains about $30 \%$ of the cross-sectional heterogeneity in the overall impact of government debt on industry growth.

In addition, we investigate several sources of non-linearity in the context of the liquidity channel. We study how vulnerabilities to sovereign debt crises, financial constraints and asset shortages affect the magnitude of the liquidity channel. We find that only vulnerabilities arising from a risky composition of domestic government debt reduce the liquidity effect of government debt on growth. The impact of high levels of domestic debt (i.e., levels greater than $60 \%$ of GDP) on the liquidity channel appears to be less robust. Our estimation results show that the size of the liquidity channel drops in countries experiencing a sovereign debt crisis and becomes irrelevant in economic terms. Our results are consistent with Eberhardt and Presbitero (2015). These authors argue that the analysis of non-linearity should go beyond the identification of common debt thresholds across countries and focus on country-specific characteristics that may alter the debt-growth relationship. In addition, we provide evidence that financial constraints at the industry level are an important factor in the relationship between liquidity-enhancing government debt and growth. We find a stronger liquidity effect of government debt on growth for sectors that rely more on external finance or with lower asset pledgeability. However, the strength of the liquidity channel does not appear to be affected by asset shortages.

Finally, we analyze the robustness of the liquidity effect of government debt on industry growth. 
We show that our baseline results are robust to using instrumental variables and controlling for many competing channels, particularly channels associated with financial development and openness. In addition, we show that the results are not sensitive to alternative specifications or driven by outliers.

This paper contributes to two strands of literature. First, it provides empirical evidence in favor of the liquidity channel of government debt. Existing research based on theoretical models shows that government debt can generate positive macroeconomic effects by providing liquid assets to financially constrained private agents. Government debt can improve welfare by relaxing households' borrowing constraints and allowing them to better smooth consumption (Aiyagari and McGrattan, 1998; Challe and Ragot, 2011). In addition, government debt can improve resource allocation when entrepreneurs are credit-constrained because of limited pledgeability (Kiyotaki and Moore, 2005; Angeletos et al., 2016). Furthermore, government debt can mitigate macroeconomic volatility by preventing bubble creation and bursts (Caballero and Krishnamurthy, 2006; Farhi and Tirole, 2012).

In addition, our paper is related to the strand of literature that empirically analyzes nonlinearities in the debt-growth link. Existing empirical research provides mixed evidence. Certain studies find that government debt is particularly harmful for growth when the debt threshold of $90 \%$ of GDP is reached (Reinhart and Rogoff, 2010a,b; Kumar and Woo, 2010; Cecchetti et al., 2011; Checherita-Westphal and Rother, 2012; Reinhart et al., 2012; Baum et al., 2013). Other studies do not find any clear-cut evidence for such a non-linear relationship between government debt and growth (Panizza and Presbitero, 2012; Kourtellos et al., 2013; Pescatori et al., 2014; Eberhardt and Presbitero, 2015; Égert, 2015). However, we are the first to empirically investigate non-linearities in the context of a specific channel.

The rest of the paper is organized as follows. The next section discusses the theoretical arguments behind the liquidity channel of government debt. Section 3 describes the empirical strategy and the data used to identify the liquidity effect of government debt on long-run industry growth. Section 4 presents the baseline results, evaluates their economic relevance and investigates non-linearities in the context of the liquidity channel. Section 5 performs a variety of robustness checks to address potential endogeneity issues and conducts sensitivity analysis. Section 6 concludes.

\section{Theoretical Motivation}

The liquidity channel of government debt builds on the seminal work by Woodford (1990) and Holmström and Tirole (1998). Their theoretical models incorporate two key features. The first key feature is the asynchronicity between a firm's access to and need for liquidity. Because of financial market imperfections, firms hold liquid financial assets to address this asynchronicity and meet future liquidity needs. The second key feature is the liquidity attribute of government debt. Firms use government debt as an asset that offers high liquidity or as a collateral that offers high collateral value. The liquidity channel works as follows. Government debt enhances the supply of 
liquid assets and facilitates firms' productive investments by relaxing their financial constraints. Therefore, firms with high liquidity needs should benefit relatively more from the crowding-in effect than firms with low liquidity needs and should also grow relatively faster in countries issuing more government debt. ${ }^{1}$

The empirical literature on corporate cash holdings and sovereign debt provides strong support for the two key features that are essential for the liquidity channel of government debt. Kim et al. (1998) and Bigelli and Sánchez-Vidal (2011) show that firms' liquidity needs that stem from asynchronicity between their access to and need for liquidity is a strong determinant of corporate cash holdings. Krishnamurthy and Vissing-Jorgensen (2012) find that investors assign a high value to the liquidity and safety attributes of U.S. Treasuries and argue that government debt is similar to money. ${ }^{2}$ Other papers show that a substantial amount of government debt is held by banks for liquidity purposes (e.g. Bolton and Jeanne, 2011; Gennaioli et al., 2014, 2016). This finding is consistent with the liquidity channel. Government debt may be indirectly held by firms through the banking sector. In an economy with financial market imperfections, firms make bank deposits to meet future liquidity needs, while banks use government debt as borrowing collateral to meet deposit withdrawals. Government debt used as collateral increases the lending capacity of banks by relaxing their financial constraints and thereby facilitates firms' real investment (e.g. Kumhof and Tanner, 2005; Saint-Paul, 2005). In line with our mechanism, a related strand of finance literature documents the positive effect of corporate liquidity on the real investment of financially constrained firms (e.g. Hoshi et al., 1991; Duchin et al., 2010; Campello et al., 2011).

The following remark is worth making at this point. We do not claim that government debt is the only available liquid asset in the economy. Clearly, firms with high liquidity needs may substitute government debt for alternative stores of value generated either by the private sector or by foreign governments (see e.g. Gorton et al., 2012; Gorton and Ordonez, 2013). However, from an empirical perspective, such a substitution would reduce the likelihood of finding any significant and positive relationship between government debt and the relative long-run growth rate of firms in sectors with high liquidity needs. Therefore, if this relationship is confirmed in the data despite the potential substitution for alternative liquid assets, the evidence in favor of the liquidity channel of government debt would be further strengthened.

\section{Empirical Strategy and Data}

\subsection{Empirical Strategy}

To test the liquidity channel of government debt, we use the difference-in-differences methodology developed by Rajan and Zingales (1998). Industries with low liquidity needs represent the con-

\footnotetext{
${ }^{1}$ In the Web Appendix, we develop a stylized growth model building on Aghion et al. (2010) to illustrate the liquidity effect of government debt on growth.

${ }^{2}$ As anecdotal evidence, in the late 1990's, practitioners were concerned about the economic consequences of government debt reduction in Europe and in the U.S. that restrained the ability of the private sector to hoard liquidity (Fleming, 2000; Reinhart and Sack, 2000).
} 
trol group for industries with high liquidity needs, and the treatment corresponds to an increase in the government debt-to-GDP ratio across countries. Government debt is decomposed into two components to identify the domestic supply of public liquidity. In a closed economy, government debt is only issued domestically. However, with financial openness, public borrowing can also occur in foreign markets. Empirical evidence provides support for a decomposition of total government debt based on the place of issuance and jurisdiction that regulates the sovereign debt contract (see Reinhart et al., 2003; Hausmann and Panizza, 2011; Reinhart and Rogoff, 2011a,b). ${ }^{3}$ Government debt issued in domestic markets under domestic law captures the domestic supply of public liquidity and therefore, represents the liquidity component of government debt. However, external government debt provides liquidity in foreign markets and fulfills the role of placebo liquidity. ${ }^{4}$ The main specification of the empirical model we estimate can be expressed as follows:

$$
g_{i c}=\beta\left(L_{i} \times D D_{c}\right)+\gamma\left(L_{i} \times E D_{c}\right)+\phi \ln y_{i c}+\alpha_{i}+\alpha_{c}+\varepsilon_{i c}
$$

where $g_{i c}$ measures the average annual growth in the real value added of industry $i$ in country $c$ over the period from $t$ to $t+n$. The variables of interest are the interaction terms $L_{i} \times D D_{c}$ and $L_{i} \times E D_{c}$, where $L_{i}$ is a measure of sectoral liquidity needs, and $D D_{c}$ and $E D_{c}$ are the levels of domestic and external government debt (relative to GDP), respectively. These ratios are averaged over the period from $t$ to $t+n$. The log of initial industry size at time $t$ denoted by $\ln y_{i c}$ is included to control for the catching-up effect. $\alpha_{i}$ is an industry fixed effect, $\alpha_{c}$ a country fixed effect and $\varepsilon_{i c}$ is a random error. The coefficient $\beta$ quantifies the liquidity effect of government debt on industry growth, while $\gamma$ captures the growth effect of placebo liquidity.

We estimate the regression equation (1) using OLS. In line with the liquidity channel of government debt, we expect to find a positive and significant estimate of $\beta$ and an insignificant estimate of $\gamma$. These results would indicate that industries with high liquidity needs grow disproportionately faster only when a government provides more domestic liquidity by issuing domestic debt. Therefore, including both interaction terms $L_{i} \times D D_{c}$ and $L_{i} \times E D_{c}$ as regressors sharpens the test of causality running from liquidity-enhancing government debt to growth. Reverse causality may bias the OLS estimation of the liquidity channel. A growth slowdown may lead to government debt build-up by deepening fiscal deficits (Easterly, 2001; Reinhart et al., 2012). However, the dependent variable measured at the sectoral level in the regression (1) mitigates the scope of reverse causality. Because the size of an industry is small relative to the size of the economy, feedback from industry

\footnotetext{
${ }^{3}$ Even considering financial globalization, Reinhart et al. (2003, p. 38) argue that it is "clearly wrong to assume that domestically-issued and foreign-issued debt are perfect substitutes. [Indeed] foreigners typically do hold a large share of externally issued debt, whereas domestic residents typically hold most domestically issued debt." (see also Reinhart and Rogoff, 2011a,b). In line with this claim, Hausmann and Panizza (2011) document that foreign participation in domestic debt markets is limited. Reinhart and Rogoff (2011a) note that the U.S. case is an exception for which all U.S. government debt is domestic, but approximately $40 \%$ is held by non-residents (mostly central banks and other official institutions).

${ }^{4}$ In the Web Appendix, we show that data from the Bank for International Settlements support the prediction that only domestic debt enhances the domestic supply of marketable government bonds.
} 
growth to government debt becomes less of an issue. ${ }^{5}$ As a robustness check, in Section 5.1 we rely on a IV estimation procedure. Omitted variables may also bias the estimates of $\beta$ and $\gamma$. However, country fixed effects control for any unobservable country-specific determinants of sectoral growth, including the level of government debt, and therefore, mitigate the omitted variable bias to a large extent. When incorporating fixed effects, the estimates of $\beta$ and $\gamma$ are biased only if an omitted variable is correlated with both sectoral liquidity needs and government debt. Section 5.2 addresses potential omitted variable bias by controlling for competitive channels that may be correlated with the interaction terms of interest and industry growth.

The panel structure of the empirical model (1) raises the problem of clustering standard errors. If not properly addressed, this problem results in a downward bias of the estimate of standard errors and leads to overrejection (Moulton, 1986, 1990; Bertrand et al., 2004). We expect unobservable growth determinants of different industries to be correlated within countries and unobservables of the same industry to be correlated across sectors. Therefore, robust standard errors are clustered in the most stringent manner by using the correction proposed by Cameron et al. (2011).

\subsection{Sectoral Measure of Liquidity Needs}

Following Rajan and Zingales (1998), the sectoral measure of liquidity needs is computed using U.S. firm-level data and extrapolated to non-U.S. industries. We use the measure of liquidity needs constructed by Raddatz (2006), which is defined as the ratio of inventories to sales for each U.S. industry. Table A.1 in Appendix A reports the measure of liquidity needs for each threedigit ISIC industry. ${ }^{6}$ Inventory investment is one of the components of investment in working capital and is particularly suitable to capture technological aspects associated with the length of the production process. Firms in industries with a low ability to finance inventories from sales are expected to undertake investment projects with long gestation periods and thus hoard more liquid assets to address the asynchronicity between their access to and need for liquidity. This mechanism suggested by Opler et al. (1999) is supported empirically. We show that the length of the cash conversion cycle that measures the average time required for inputs to generate an output is highly correlated with the ratio of inventories to sales across sectors. ${ }^{7}$ Kim et al. (1998) and Bigelli and Sánchez-Vidal (2011) find that firms with longer cash conversion cycles hold relatively more liquid assets.

Therefore, we rely on a US-based industry-specific measure of liquidity needs to estimate the liquidity effect of government debt on growth. The validity of this empirical strategy is based on two basic assumptions. First, there are technological reasons why certain industries undertake projects with long gestation periods, hence they have a high ratio of inventories to sales. Because

\footnotetext{
${ }^{5}$ In our sample, the largest sector corresponds to $6.3 \%$ of GDP.

${ }^{6}$ The original measure of Raddatz (2006) is reported at the four-digit ISIC level. Because data on industry growth are available at the three-digit ISIC level, we use the index of liquidity needs recomputed by Aghion et al. (2009) at this level of disaggregation.

${ }^{7}$ We find a coefficient of correlation of 0.92. For more details see Table A.1 in Appendix A. In addition, we use the cash conversion cycle as an alternative measure for liquidity needs in Table 6 for the robustness checks.
} 
the U.S. economy can be considered as relatively frictionless and thus represents a good benchmark, the computation of liquidity needs from U.S. data should reflect exogenous characteristics of sectoral production technology. Second, technological differences underlying the ranking of liquidity needs across industries persist across countries. Raddatz (2006) provides empirical evidence supporting both of these assumptions.

\subsection{Data on Government Debt and Industry Growth}

Data on the level and composition of government debt are obtained from Panizza (2008). This dataset relies on several publicly available sources and includes information regarding the central government debt of up to 130 countries for the period 1990-2007. ${ }^{8}$ Information is provided on the fraction of total government debt issued domestically under domestic law and in foreign countries under foreign law. We construct a cross-sectional panel by averaging domestic and external government-to-GDP ratios over the period 1991-2000. Sectoral growth is measured using data on value added at the industry level that are collected annually by the United Nations Industrial Development Organization (UNIDO). Specifically, we use the database compiled by Nicita and Olarreaga (2007), which includes data for 100 countries over the period 1976-2004. These data are disaggregated into 28 industries in the manufacturing sector according to the ISIC Rev. 2 classification. Long-run growth at the sectoral level is defined as the average annual real growth rate of value added by ISIC sector for each country over the period 1990-2000. ${ }^{9}$ The period 1990-2000 is the longest span of time that maximizes the number of countries to be considered. For most of the 100 countries included in the database, data on value added are missing after 2000.

Due to differences in the countries that are included in datasets on government debt and industry growth, the baseline regression sample includes 39 countries. The resulting dataset is an unbalanced panel of 39 countries associated with 899 observations (rather than $1092=39 \times 28$ possible observations). Because the sectoral measure of liquidity needs is calculated using U.S. data, we follow Rajan and Zingales (1998) by dropping the U.S. to address the potential endogeneity problem. Table A.3 in Appendix B lists the countries included in the baseline regression with the respective number of industries. Figure 2 shows the composition of government debt during the 1990's across the 39 countries included in our baseline regression sample.

\footnotetext{
${ }^{8}$ When data on central government debt are not available, Panizza (2008) uses data from the general government and the non-financial public sector. Only three countries are considered in the baseline regression sample: Panama (general government), Tunisia and Uruguay (non-financial public sector).

${ }^{9} \mathrm{We}$ do not exploit the time dimension of the data for two reasons. First, we focus on long-run growth and a lack of data prevents exploiting more than one decade. Second, we choose an identification stemming purely from the cross-sectional variation in government debt because the time series variation of government domestic and external debt within countries in our sample only represents one-tenth of the total variation.
} 


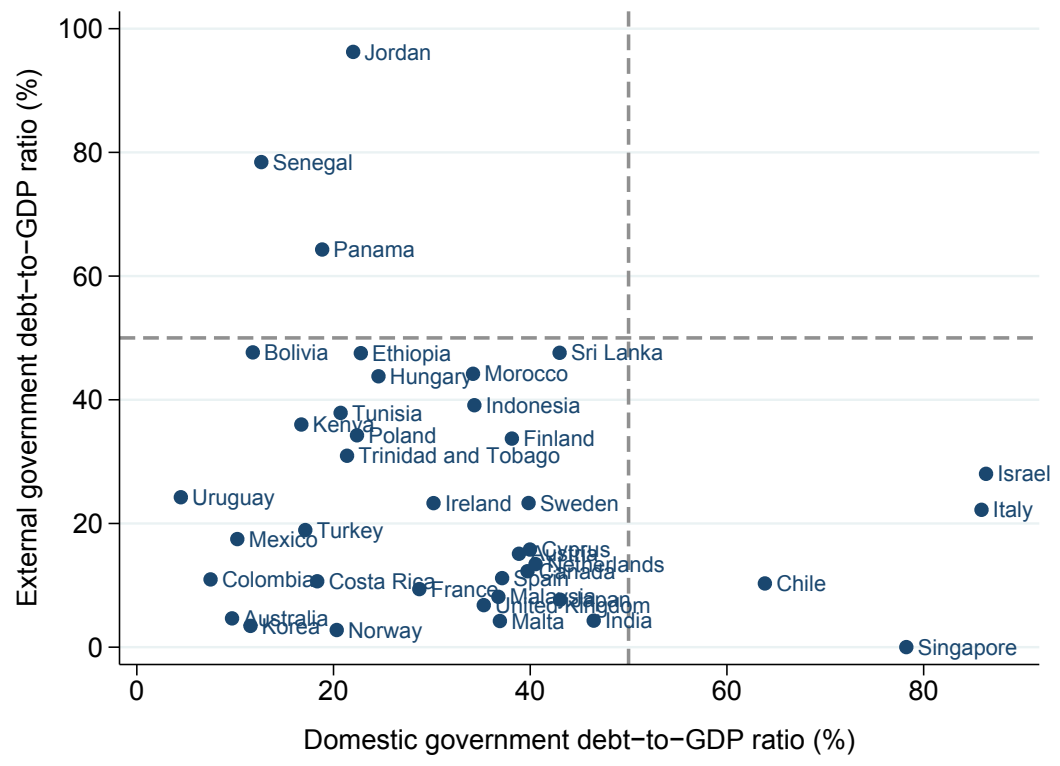

Figure 1

The Cross-Sectional Composition of Government Debt

Notes: This figure plots the external government debt-to-GDP ratio for a cross-section of 39 countries included in the baseline regression against the domestic government debt-to-GDP ratio. Both ratios are averaged over the period 1991-2000 and are obtained from Panizza (2008). 
TABLE 1

The Liquidity Effect of Government Debt on Industry Growth

\begin{tabular}{|c|c|c|c|c|c|c|c|c|}
\hline & $(1)$ & $(2)$ & (3) & (4) & (5) & (6) & (7) & $(8)$ \\
\hline \multicolumn{9}{|l|}{ A. Total debt } \\
\hline $\begin{array}{l}\text { Liquidity needs } \times \text { Total debt } \\
\left(L_{i} \times T D_{c}\right)\end{array}$ & $\begin{array}{c}0.189^{* *} \\
(0.084)\end{array}$ & & & & & & & \\
\hline \multicolumn{9}{|l|}{ B. Domestic debt vs. External debt } \\
\hline $\begin{array}{l}\text { Liquidity needs } \times \text { Domestic debt } \\
\left(L_{i} \times D D_{c}\right)\end{array}$ & & $\begin{array}{c}0.651^{* *} \\
(0.277)\end{array}$ & & $\begin{array}{c}0.610^{* *} \\
(0.246)\end{array}$ & $\begin{array}{c}0.581^{* *} \\
(0.231)\end{array}$ & $\begin{array}{c}0.592^{* *} \\
(0.233)\end{array}$ & $\begin{array}{c}0.426^{* *} \\
(0.212)\end{array}$ & $\begin{array}{c}0.616^{* *} \\
(0.170)\end{array}$ \\
\hline $\begin{array}{l}\text { Liquidity needs } \times \text { External debt } \\
\left(L_{i} \times E D_{c}\right)\end{array}$ & & & $\begin{array}{l}-0.196 \\
(0.283)\end{array}$ & $\begin{array}{l}-0.175 \\
(0.204)\end{array}$ & $\begin{array}{l}-0.135 \\
(0.176)\end{array}$ & $\begin{array}{l}-0.265 \\
(0.237)\end{array}$ & $\begin{array}{l}-0.177 \\
(0.207)\end{array}$ & $\begin{array}{l}-0.177 \\
(0.212)\end{array}$ \\
\hline Domestic debt & & & & & $\begin{array}{l}-0.057 \\
(0.047)\end{array}$ & & & \\
\hline External debt & & & & & $\begin{array}{c}0.029 \\
(0.032)\end{array}$ & & & \\
\hline Liquidity needs & & & & & & $\begin{array}{c}-0.259^{* *} \\
(0.077)\end{array}$ & & \\
\hline Tangibiliy $\times$ Domestic debt & & & & & & & $\begin{array}{l}-0.094 \\
(0.101)\end{array}$ & \\
\hline Financial dependence $\times$ Domestic debt & & & & & & & & $\begin{array}{c}0.095^{* *} \\
(0.043)\end{array}$ \\
\hline Initial industry share & $\begin{array}{c}-0.011^{* *} \\
(0.005)\end{array}$ & $\begin{array}{c}-0.008^{*} \\
(0.005)\end{array}$ & $\begin{array}{c}-0.010^{* *} \\
(0.005)\end{array}$ & $\begin{array}{c}-0.008^{*} \\
(0.005)\end{array}$ & $\begin{array}{c}-0.010^{* *} \\
(0.005)\end{array}$ & $\begin{array}{l}-0.001 \\
(0.005)\end{array}$ & $\begin{array}{c}-0.008^{*} \\
(0.005)\end{array}$ & $\begin{array}{c}-0.009^{* *} \\
(0.005)\end{array}$ \\
\hline Industry fixed effects & Yes & Yes & Yes & Yes & Yes & No & Yes & Yes \\
\hline Country fixed effects & Yes & Yes & Yes & Yes & No & Yes & Yes & Yes \\
\hline Causal effect (in pp) & 0.14 & 0.49 & - & 0.46 & 0.44 & 0.44 & 0.32 & 0.46 \\
\hline Observations & 937 & 899 & 927 & 899 & 899 & 899 & 899 & 899 \\
\hline Countries & 41 & 39 & 40 & 39 & 39 & 39 & 39 & 39 \\
\hline
\end{tabular}

Notes: All regressions include both industry and country fixed effects and a constant (except in columns (5) and (6) where country and industry fixed effects are excluded, respectively). The dependent variable is the annual compounded growth rate in real value added over the period 1990-2000 for each 3-digit ISIC industry in each country. The variables of interest $L_{i} \times T D_{c}, L_{i} \times D D_{c}$ and $L_{i} \times E D_{c}$ denote the product of these two variables. Liquidity needs $L_{i}$ from Raddatz (2006) is measured as the ratio of inventories to sales in each 3-digit ISIC U.S. industry. Data on government debt are obtained from Panizza (2008). $D D_{c}$ is government debt issued domestically under domestic law relative to GDP, while $D D_{c}$ is government debt issued in foreign countries under foreign law relative to GDP. Domestic and external government debt-to-GDP ratios are averaged over the period 1991-2000. Total debt $T D_{c}$ is the sum of $D D_{c}$ and $E D_{c}$. In columns (7) and (8), we interact $D D_{c}$ with asset tangibility from Braun and Larrain (2005) and external financial dependence from Rajan and Zingales (1998). Asset tangibility is defined as the industry-specific ratio of net property, plant and equipment to total assets, while external financial dependence is defined as the industry-specific ratio of capital expenditures minus cash-flows from operations to capital expenditures. The initial industry share is defined as the (log) share of industry value added to total value added in 1990 . The causal effect in percentage points measures the change in growth for an industry at the 75 th percentile of liquidity needs relative to an industry at the 25 th percentile after an increase in the government debt-to-GDP ratio by 10 percentage points. Columns (1)-(8) report the OLS estimates. Robust standard errors reported in parentheses are adjusted for two-way clustering at the industry and country level. **: significant at the $5 \%$ level. *: significant at the $10 \%$ level. 


\section{Empirical Results}

\subsection{Baseline Results}

We test the liquidity channel of government debt by estimating different versions of the regression equation (1). In Panel A of Table 1, we consider total government debt. In Panel B, total government debt is decomposed into domestic and external debt to disentangle the domestic supply of public liquidity from the placebo liquidity. The estimation results are presented in Table 1.

The estimation results shown in columns (1)-(4) provide support for a positive liquidity effect of government debt on industry growth. The estimated coefficient on the interaction term $L_{i} \times T D_{c}$ in Panel A is positive and statistically significant at the $5 \%$ level. In Panel $\mathrm{B}$, the interaction with domestic debt $L_{i} \times D D_{c}$ has a significant and positive effect on industry growth, whereas the interaction with external debt $L_{i} \times E D_{c}$ is insignificant. ${ }^{10}$ These results show that an increase in the level of government debt promotes relatively more long-run growth of real value added in sectors with high liquidity needs only if it leads to a larger domestic supply of public liquidity. Industries with high liquidity needs do not grow significantly faster than those with low liquidity needs in countries with higher levels of external government debt. The insignificant growth effect of external government debt as placebo liquidity provided in columns (3) and (4) sharpens the causal interpretation of our results.

Empirical specification (1) does not allow us to identify the country-wide effect of government debt on industry growth since this effect is subsumed in the country fixed effects. It might be interesting to investigate whether domestic government debt affects industry growth primarily through the liquidity channel, as opposed through a general effect, such as larger subsidies or more favorable taxation of the manufacturing sector. To do so, we exclude country fixed effects and include domestic and external government debt-to-GDP ratios as regressors. The estimation results in column (5) do not indicate any significant country-wide effect of domestic or external debt on industry growth. Importantly, the presence of domestic and external government debt as explanatory variables does not change the magnitude nor the significance of the liquidity channel of government debt. The interaction of liquidity needs and external government debt as placebo liquidity remains insignificant. This finding suggests that the main interaction term of interest $L_{i} \times D D_{c}$ identifies the growth effect of government debt operating through the liquidity channel. It might also interesting to examine whether liquidity needs impede industry growth, while domestic debt mitigates this negative effect by contributing to the domestic supply of liquidity. We estimate our main regression without industry fixed effects by adding liquidity needs as an explanatory variable. The results in column (6) confirm the empirical relevance of this mechanism.

The industry-specific measure of liquidity needs could be correlated with characteristics capturing financial frictions at the sectoral level. Therefore, we may capture a channel through which domestic government debt helps industries overcome financial frictions independently of their liquidity needs. Financially constrained sectors may be more dependent on government bonds to borrow from the

\footnotetext{
${ }^{10}$ The $p$-value of the estimated coefficient on $L_{i} \times E D_{c}$ is equal to 0.489 in column 3 and 0.393 in column 4 .
} 
credit market. We rely on two industry-specific measures of financial frictions widely used in the finance literature to disentangle the liquidity channel from a channel related to financial frictions. In column (7), we include the interaction of asset tangibility from Braun and Larrain (2005) and domestic government debt. In column (8), we add the interaction term with external financial dependence from Rajan and Zingales (1998) as a proxy for industry-level financial frictions. ${ }^{11}$ For both specifications, the variable of interest, $L_{i} \times D D_{c}$, maintains a positive and significant coefficient, while the magnitude of the liquidity channel is lower in column (7).

\subsection{Magnitude of the Liquidity Channel of Government Debt}

Is the liquidity channel of government debt economically relevant? We assess its economic magnitude by using the estimation results in Table 1 .

First, we calculate the change in growth in an industry with high liquidity needs (ranked at the 75th percentile of the distribution) relative to an industry with low liquidity needs (ranked at the 25th percentile) after an increase in the domestic government debt-to-GDP ratio by 10 percentage points. This difference-in-differences effect reported in Table 1 can be interpreted as causal and is economically relevant. ${ }^{12}$ According to the estimate in column (4) of Table 1, an increase in the domestic government debt-to-GDP ratio by 10 percentage points would boost annual real growth of the "machinery" industry with high liquidity needs by 0.5 percentage points relative to the "wood products" industry with low liquidity needs. This corresponds to about one quarter of the average annual industry growth in our sample (equal to $1.86 \%$ ). The causal effect drops to 0.15 percentage points when total government debt is considered in column (1). This result occurs because of the insignificant liquidity effect of external government debt on industry growth.

Next, we quantify the magnitude of the liquidity channel relative to other potential channels through which government debt may heterogeneously affect industry growth. To do so, we run the following regression:

$$
g_{i c}=\beta_{i}\left(D_{i} \times D D_{c}\right)+\gamma_{i}\left(D_{i} \times E D_{c}\right)+\phi \ln y_{i c}+\alpha_{i}+\alpha_{c}+\varepsilon_{i c}
$$

where $D_{i}$ is an industry dummy. The common overall impact of government debt on industry growth is captured by country fixed effects $\alpha_{c}$, while the coefficients $\beta_{i}$ (resp. $\gamma_{i}$ ) measure the heterogeneous overall effect of domestic government debt (resp. external government debt) across sectors. One can then regress the OLS estimates of $\beta_{i}$ and $\gamma_{i}$ on sectoral liquidity needs to investigate the extent to which the liquidity channel explains the cross-sectional heterogeneity of the overall growth effect of government debt. Graphs in Figure 2 summarize our findings.

The $R^{2}$ amounts to $29 \%$ for domestic debt, but drops to $2 \%$ for external debt. Therefore, the liquidity channel explains a significant fraction of the cross-sectional heterogeneity in the overall effect of government debt on industry growth. This result can also be interpreted as evidence of

\footnotetext{
${ }^{11}$ Asset tangibility is highly correlated with liquidity needs, while external financial dependence is found to be uncorrelated. See Table A.2. in Appendix A.

${ }^{12}$ The causal effect is calculated as $\widehat{\beta} \times\left(L_{\text {high }}-L_{\text {low }}\right) \times 0.1$.
} 


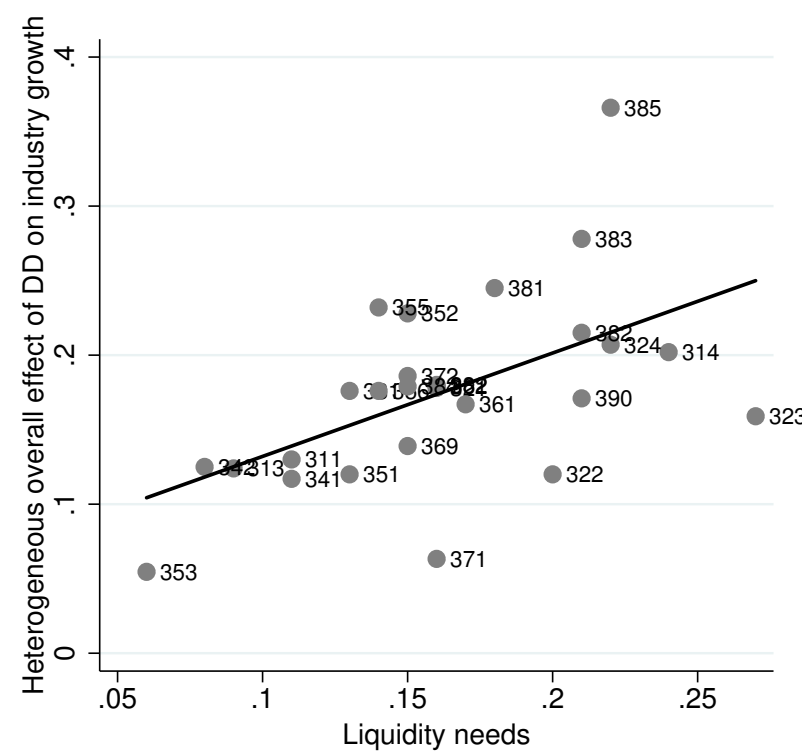

Coeff $=0.69$, Robust se $=0.25, \mathrm{t}-$ stat $=2.79, \mathrm{R}$-squared $=0.29$

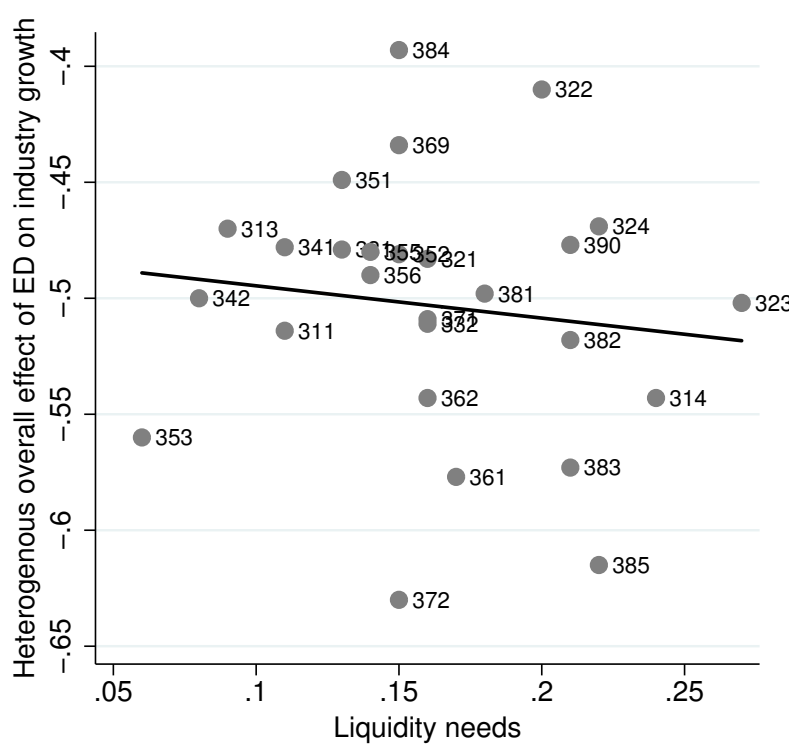

Coeff $=-0.14$, Robust se $=0.19, \mathrm{t}-\mathrm{stat}=-0.72, \mathrm{R}-$ squared $=0.02$

Figure 2

The Relative Magnitude of the Liquidity Channel

Notes: The graph on the left (graph on the right) is a scatter plot of the heterogeneous overall effect of domestic government debt (DD) (external government debt (ED)) on industry growth against the measure of liquidity needs from Raddatz (2006). These effects are obtained from the OLS estimates of $\beta_{i}$ and $\gamma_{i}$ in regression (2). Estimates of $\beta_{i}$ and $\gamma_{i}$ for the industry "Miscellaneous petroleum and coal products" (ISIC 354) (equal to 0.684 and -0.841 , respectively) are outliers and thus are excluded.

the economic relevance of the liquidity channel relative to other potential channels through which government debt may affect growth. ${ }^{13}$

\subsection{Investigating Non-Linearities}

A significant part of the empirical literature on the debt-growth nexus is dedicated to identifying debt thresholds above which this relationship changes (see e.g. Reinhart and Rogoff, 2010a,b; Kumar and Woo, 2010; Cecchetti et al., 2011; Checherita-Westphal and Rother, 2012; Reinhart et al., 2012; Baum et al., 2013; Panizza and Presbitero, 2012; Kourtellos et al., 2013; Pescatori et al., 2014; Eberhardt and Presbitero, 2015; Égert, 2015). We depart from existing research by examining several sources of non-linearities in the context of the liquidity channel. We study how vulnerabilities to sovereign debt crises, financial constraints and asset shortages affect the magnitude of the liquidity channel. Our basic test of non-linearity in the context of the liquidity channel consists in running the following regression:

$$
g_{i c}=\beta_{0}\left(L_{i} \times D D_{c}\right)+\beta_{1}\left(L_{i} \times D D_{c} \times S_{i / c}\right)+\phi \ln y_{i c}+\alpha_{i}+\alpha_{c}+\varepsilon_{i c}
$$

\footnotetext{
${ }^{13}$ In the Web Appendix, we repeat this exercise by excluding each country from the sample and find that our results are not driven by a particular country.
} 
where $S_{i / c}$ is a variable capturing an industry-specific or country-specific source of non-linearity. The coefficient of interest is $\beta_{1}$. We expect a negative and significant value for $\beta_{1}$ in countries vulnerable to sovereign debt crises and a positive and significant value for $\beta_{1}$ when industries are financially constrained or must deal with asset shortages. This findings would indicate that vulnerabilities to sovereign debt crises reduce the liquidity effect of government debt on industry growth, while financial constraints and asset shortages amplify it.

Our strategy is consistent with Eberhardt and Presbitero (2015), which argues that the analysis of non-linearity should go beyond the identification of common debt thresholds across countries and focus on country-specific characteristics that may change the debt-growth relationship. Following this argument, Kourtellos et al. (2013) investigate threshold variables other than the debt-to-GDP ratio by relying on cross-country regressions. However, as previously argued, our cross-country/cross-industry analysis based on the RZ methodology is less prone to endogeneity issues. Furthermore, our analysis provides a direct test of a non-linear causal effect running from government debt to industry growth through the liquidity channel.

\subsubsection{The Role of Vulnerabilities to Sovereign Debt Crises}

Government debt enhances the supply of liquid assets during normal periods, while sovereign default destroys it. Existing literature shows that liquidity destruction arising from sovereign debt crises generates large economic costs (see e.g. Basu, 2009; Bolton and Jeanne, 2011; Brutti, 2011; Gennaioli et al., 2014, 2016). We expect to find that the strength of the liquidity channel is mitigated in countries vulnerable to sovereign debt crises due to expectations of liquidity destruction.

Vulnerabilities depend on both level and composition of government debt (Reinhart et al., 2003; Eichengreen et al., 2007; Dell'Erba et al., 2013). In Table 2A, we first examine whether the level of government debt affects the magnitude of the liquidity channel. We exploit the "natural" break point stressed in Figure 2 by choosing a threshold for domestic government debt at 60 percent of GDP. In addition, we apply the methodology from Hansen (1999) to endogenously select the threshold level. We find a point estimate at 43 percent of GDP. ${ }^{14}$ We construct two indicator variables, $D_{d o m>60 \%}$ and $D_{d o m>43 \%}$, that take the value of one for countries with a level of domestic debt above these thresholds. According to the estimates in columns (1) and (2), the liquidity effect of government debt on industry growth remains positive but is significantly lower in countries with high levels of domestic government debt. In quantitative terms, the liquidity effect is reduced by half when a country reaches this threshold. Interestingly the estimated coefficient for the interaction term $L_{i} \times D D_{c}$ is twice as large as in the baseline regressions of Table 1 once we control for high domestic debt levels. In contrast, the results in columns (3) and (4) indicate no significant non-linear effect of high levels of total government debt (i.e., above $60 \%$ of GDP). A comparison with existing literature on non-linearities in the debt-growth relationship is worth making. First, we find a debt threshold associated with negative liquidity effect only for domestic debt, while existing empirical

\footnotetext{
${ }^{14}$ See the Web Appendix for more details. However, note that the threshold estimate is insignificant at the $10 \%$ level.
} 
research estimates a debt threshold for total debt. Second, our debt threshold is lower than the 90\% threshold reported by current studies (Reinhart and Rogoff, 2010a,b; Kumar and Woo, 2010; Cecchetti et al., 2011; Checherita-Westphal and Rother, 2012; Reinhart et al., 2012; Baum et al., 2013). One potential explanation may be that the liquidity channel does not emcompass negative effects originating from high levels of external debt.

In columns (5)-(7) of Table $2 \mathrm{~A}$, we examine the role of risk stemming from the composition of domestic government debt. Vulnerabilities may arise from short-term debt because of roll-over risk and maturity mismatch, from foreign currency denominated debt because of currency mismatch and from indexed debt because of contingent interest payments. Therefore, we treat domestic debt as risky if it is short-term, denominated in foreign currency and indexed. We use data on the share of risky domestic government debt in emerging economies from Mehl and Reynaud (2010) and data on OECD countries from Falcetti and Missale (2002). Because of a lack of data on the risky composition, 15 countries were removed from the sample. The results in column (5) show that government debt appears to have virtually no liquidity effect on growth if only risky domestic debt is issued. In column (7), we conduct a horse race between vulnerabilities arising from risky level and risky composition. In columns (6), we run the same regression as in column (1) of Table 1 but use the reduced sample. We find that the risky composition in column (7) to a large extent absorbs the negative liquidity effect of high debt levels from column (6). This result occurs because countries with high levels of domestic government debt also have the riskiest composition. ${ }^{15}$ This result provides evidence of the dominance of risky composition over risky level for explaining how vulnerabilities to sovereign debt crises mitigate the strength of the liquidity channel. ${ }^{16}$

In column (8), we analyze the effect of a sovereign debt crisis on the strength of the liquidity channel. Following Laeven and Valencia (2013), we construct a crisis dummy that takes the value of one if the country experiences an episode of default and restructuring during the 1990's. Our estimation results show that sovereign debt crises significantly reduce the liquidity effect of government debt on industry growth, while the effect of vulnerabilities arising from high debt levels remains negative but becomes insignificant. The size of the liquidity channel in crisis countries is four times smaller than in non-crisis countries and becomes irrelevant in economic terms. ${ }^{17}$ In columns (9) and (10), we examine whether inflation and exchange rate risks are relevant sources of non-linearities in the context of the liquidity channel. Countries with lower inflation and exchange rate risk tend to have a safer debt composition (Hausmann and Panizza, 2003; Mehl and Reynaud, 2010) and should be less vulnerable to sovereign debt crises. We do not find that inflation or exchange rate risk has a significant effect on the liquidity channel, although their estimates have

\footnotetext{
${ }^{15}$ On average, the share of risky domestic government debt over the period $1991-2000$ is $45 \%$ for countries with a ratio of domestic government debt below 60 percent of GDP. This share appears to be 26 percentage points higher for countries above the $60 \%$ debt threshold.

${ }^{16}$ Non-linearities arising from high domestic debt levels do not appear to be robust once we control for alternative relevant channels (see column (8) in Table $2 \mathrm{~A}$ and column (3) in Table 2B).

${ }^{17}$ In crisis countries, an increase in the domestic government debt-to-GDP ratio by 10 percentage points would boost annual real growth of the "machinery" industry with high liquidity needs by 0.2 percentage points relative to the "wood products" industry with low liquidity needs.
} 
TABLE $2 \mathrm{~A}$

Non-Linear Liquidity Effects of Government Debt on Industry Growth: the Role of Vulnerability to Sovereign Debt Crises

\begin{tabular}{|c|c|c|c|c|c|c|c|c|c|c|}
\hline & \multicolumn{4}{|c|}{ Risky level } & \multicolumn{3}{|c|}{ Risky composition } & \multirow{2}{*}{$\begin{array}{c}\begin{array}{c}\text { Debt } \\
\text { crisis }\end{array} \\
(8)\end{array}$} & \multirow{2}{*}{$\begin{array}{c}\begin{array}{c}\text { Inflation } \\
\text { risk }\end{array} \\
(9)\end{array}$} & \multirow{2}{*}{$\begin{array}{c}\begin{array}{c}\text { Exchange } \\
\text { rate risk }\end{array} \\
(10)\end{array}$} \\
\hline & (1) & (2) & (3) & (4) & (5) & (6) & (7) & & & \\
\hline $\begin{array}{l}\text { Liquidity needs } \times \text { Domestic debt } \\
\left(L_{i} \times D D_{c}\right)\end{array}$ & $\begin{array}{l}1.221^{* *} \\
(0.517)\end{array}$ & $\begin{array}{l}1.264^{* *} \\
(0.578)\end{array}$ & $\begin{array}{l}0.788^{*} \\
(0.453)\end{array}$ & $\begin{array}{l}1.135^{* *} \\
(0.523)\end{array}$ & $\begin{array}{c}0.872^{* *} \\
(0.163)\end{array}$ & $\begin{array}{l}0.828^{*} \\
(0.426)\end{array}$ & $\begin{array}{c}0.930^{* *} \\
(0.394)\end{array}$ & $\begin{array}{l}1.040^{* *} \\
(0.482)\end{array}$ & $\begin{array}{l}1.294^{* *} \\
(0.463)\end{array}$ & $\begin{array}{c}1.273^{* *} \\
(0.460)\end{array}$ \\
\hline Liquidity needs $\times$ Domestic debt $\times D_{\text {dom }>60 \%}$ & $\begin{array}{c}-0.590^{* *} \\
(0.301)\end{array}$ & & & $\begin{array}{c}-0.794^{* *} \\
(0.356)\end{array}$ & & $\begin{array}{l}-0.385 \\
(0.272)\end{array}$ & $\begin{array}{l}-0.096 \\
(0.360)\end{array}$ & $\begin{array}{l}-0.347 \\
(0.238)\end{array}$ & $\begin{array}{c}-0.590^{* *} \\
(0.291)\end{array}$ & $\begin{array}{c}-0.580^{* *} \\
(0.327)\end{array}$ \\
\hline Liquidity needs $\times$ Domestic debt $\times D_{\text {dom }>43 \%}$ & & $\begin{array}{c}-0.576^{*} \\
(0.328)\end{array}$ & & & & & & & & \\
\hline Liquidity needs $\times$ Domestic debt $\times D_{\text {tot }>60 \%}$ & & & $\begin{array}{l}-0.140 \\
(0.243)\end{array}$ & $\begin{array}{c}0.291 \\
(0.269)\end{array}$ & & & & & & \\
\hline Liquidity needs $\times$ Domestic debt $\times S_{\text {other }}$ & & & & & $\begin{array}{c}-0.708^{* *} \\
(0.150)\end{array}$ & & $\begin{array}{c}-0.633^{* *} \\
(0.298)\end{array}$ & $\begin{array}{c}-0.756^{* *} \\
(0.234)\end{array}$ & $\begin{array}{l}-0.176 \\
(0.260)\end{array}$ & $\begin{array}{l}-0.062 \\
(0.261)\end{array}$ \\
\hline Initial industry share & Yes & Yes & Yes & Yes & Yes & Yes & Yes & Yes & Yes & Yes \\
\hline Fixed effects & Yes & Yes & Yes & Yes & Yes & Yes & Yes & Yes & Yes & Yes \\
\hline Observations & 899 & 899 & 899 & 899 & 586 & 586 & 586 & 899 & 899 & 839 \\
\hline Countries & 39 & 39 & 39 & 39 & 24 & 24 & 24 & 39 & 39 & 39 \\
\hline
\end{tabular}

Notes: All regressions include both industry and country fixed effects and a constant. The dependent variable is the annual compounded growth rate in real value added over the period 1990-2000 for each 3-digit ISIC industry in each country. The indicator variable $D_{d o m>60 \%}\left(D_{t o t>60 \%}\right)$ takes the value of one for countries with domestic (total) government debt above 60 percent of GDP. The indicator variable $D_{\text {dom }}>43 \%$ takes the value of one for countries with domestic government debt above 43 percent of GDP, which corresponds to the estimated threshold using the methodology from Hansen (1999). In columns (5)-(7), the source of non-linearities $S_{\text {other }}$ is risky composition, which is defined as the share of risky domestic government debt from Mehl and Reynaud (2010) and Falcetti and Missale (2002). Domestic debt is treated as risky if it is short-term, denominated in foreign currency and indexed. The remaining sources of non-linearities $S_{\text {other }}$ include dummy variables taking the value of one in the following columns: (8) if the country experiences an episode of default and restructuring during the 1990's following Laeven and Valencia (2013); (9) for countries above the median of the index of monetary freedom from Gwartney et al. (2010); and (10) for countries under a flexible exchange rate regime over the period 1991-2000 (average coarse grid larger than 1) according to the coarse classification from Reinhart and Rogoff (2004). The remaining variables are defined in Table 1. Columns (1)-(10) report the OLS estimates. Robust standard errors reported in parentheses are adjusted for two-way clustering at the industry and country level. **: significant at the $5 \%$ level. *: significant at the $10 \%$ level. 
the expected negative sign.

\subsubsection{The Role of Financial Constraints and Asset Shortages}

As outlined in the theoretical motivation, firms use government debt as a liquid asset to meet future liquidity needs because of financial constraints. Therefore, we expect to find a stronger liquidity effect of government on growth in financially constrained industries. We test this source of nonlinearities in columns (1)-(4) of Table 2B by relying on various proxies for financial constraints extensively used in the finance literature. First, we use two industry-specific measures of financial constraints: external finance dependence from Rajan and Zingales (1998) and the pledgeability of real assets based on their redeployability from Beutler and Grobéty (2011). ${ }^{18}$ We rely on two country-specific measures of financial constraints: the average private bank credit relative to GDP over the period 1991-2000 and the index of creditor rights from Djankov et al. (2007). Estimation results in columns (1) and (2) support the hypothesis that financial constraints at the industry level are an important factor in the relationship between liquidity-enhancing government debt and growth. We find a stronger liquidity effect of government debt on growth for sectors with heavier reliance on external finance or with lower asset pledgeability. However, the estimation results in columns (3) and (4) show that the strength of the liquidity channel does not appear to be significantly different for industries located in countries with lower ratios of private credit to GDP or with weaker creditor rights.

Another reason for non-linearities is that firms with high liquidity needs substitute government debt for alternative liquid assets. Therefore, we may find that the liquidity channel becomes stronger in countries where firms do not have access to domestic or foreign financial assets. We compute a country-specific index of asset shortages for the period 1991-2000 following Chen and Imam (2013). This index measures the difference between the demand for stores of value and the ability of the economy to generate them. Gross national savings is used as a proxy for the demand for stores of value, whereas the capacity to generate them is defined as the issuance of loans, bonds, equity and the accumulation of net foreign assets. We rely on two indices: an index of global asset shortages that includes the issuance of public bonds and an index of private asset shortage that excludes it. In addition, we use an indicator of financial openness from Chinn and Ito (2006) based on the intensity of capital controls. If a country is financially closed, firms cannot access foreign liquid assets such as U.S. Treasury bills that may be close substitutes to domestic government debt. The asset shortage interaction enters regressions (5)-(7) of Table $2 \mathrm{~B}$ with an insignificant sign, suggesting that asset shortages do not change the liquidity effect of government debt on industry growth.

Finally, economic development does not appear to be a relevant source of non-linearity. According to the results in columns (8) and (9), the liquidity channel is not significantly different in high

\footnotetext{
${ }^{18}$ The industry-specific measure of asset tangibility from Braun and Larrain (2005) is also frequently used as a proxy for asset pledgeability. Because of the strong negative correlation with liquidity needs, the use of tangibility would capture non-linearities arising from liquidity needs, not financial constraints. The measure from Beutler and Grobéty (2011) offers the advantage of being uncorrelated with liquidity needs (see Table A.2 in the Appendix).
} 
income countries or in OECD countries. In column (10), we investigate whether the low turnover of government bonds weakens the liquidity effect of the level of government debt on industry growth because the size of the government bond market may not coincide with market liquidity (see e.g. Levine and Zervos, 1998). Unfortunately, data on the turnover ratio for public and private bond markets are not available for a large cross-section of countries. We use the turnover ratio for stock markets as a proxy. We construct an indicator taking the value of one for countries below the median of the stock market turnover ratio. A lack of market liquidity appears to reduce the magnitude of the liquidity channel because the low turnover interaction enters regression (10) with the expected negative and significant sign.

\section{Robustness checks}

We analyze the robustness of our baseline results by addressing potential endogeneity issues due to reverse causality and omitted variables. First, we use an instrumental variable approach to control for the potential feedback from industry growth to government debt. Second, we control for a wide range of competing channels that may spuriously drive the liquidity effect of government debt on growth. In addition, we test the sensitivity of our baseline results to alternative motives for liquidity needs, alternative measures of the dependent variable and influential observations.

\subsection{Instrumental Variables}

Reverse causality may bias the OLS estimation of the liquidity effect of government debt on industry growth. The direction of bias remains an empirical question. If the growth of industries with high liquidity needs is a key driver for public deficits and debt, the OLS estimate of the coefficients $\beta$ and $\gamma$ in regression (1) is biased downward. An upward bias might occur if the feedback from industry growth to government debt arises from sectors with low liquidity needs. However, such feedback effects are expected to be negligible because the size of manufacturing industries is small relative to the size of the economy.

We estimate the baseline regressions in columns (1)-(4) of Table 1 by instrumenting government debt with three instrumental variables: the initial government debt-to-GDP ratio in 1990, and measures of the tax burden and the extent of government spending over the period 1991-2000. The ability of our IV estimation procedure to solve the potential issue of reverse causality relies on the exogeneity and relevance of our instruments. First, the exclusion restrictions require that our instruments only indirectly affect the growth of industries with high liquidity needs through their impact on government debt. From an economic perspective, these instruments are appropriate. Initial government debt is shaped by past economic performance and political decisions and can be considered as a predetermined variable. Tax burden and government spending may not satisfy the exclusion restrictions if fiscal policy systematically targets industries with high or low liquidity needs. However, finding support for this argument in a cross-section of countries appears unlikely. ${ }^{19}$

\footnotetext{
${ }^{19}$ There is no significant impact of the interaction terms between these fiscal policy variables and liquidity needs
} 
TABLE 2B

Non-Linear Liquidity Effects of Government Debt on Industry Growth: the Role of Financial constraints and Asset Shortages

\begin{tabular}{|c|c|c|c|c|c|c|c|c|c|c|}
\hline & \multicolumn{4}{|c|}{ Financial constraints } & \multicolumn{3}{|c|}{ Asset shortages } & \multicolumn{3}{|c|}{ Other } \\
\hline & $\begin{array}{l}\text { Financial } \\
\text { dep. }\end{array}$ & $\begin{array}{l}\text { Asset } \\
\text { pledge. }\end{array}$ & $\begin{array}{l}\text { Private } \\
\text { credit }\end{array}$ & $\begin{array}{l}\text { Creditor } \\
\text { rights }\end{array}$ & $\begin{array}{c}\text { Global } \\
\text { shortages }\end{array}$ & $\begin{array}{l}\text { Private } \\
\text { shortages }\end{array}$ & $\begin{array}{l}\text { Financial } \\
\text { openness }\end{array}$ & $\begin{array}{l}\text { High } \\
\text { income }\end{array}$ & OECD & $\begin{array}{l}\text { Low } \\
\text { turnover }\end{array}$ \\
\hline & (1) & (2) & (3) & (4) & (5) & (6) & (7) & (8) & (9) & (10) \\
\hline $\begin{array}{l}\text { Liquidity needs } \times \text { Domestic debt } \\
\left(L_{i} \times D D_{c}\right)\end{array}$ & $\begin{array}{l}1.080^{* *} \\
(0.472)\end{array}$ & $\begin{array}{l}1.043^{* *} \\
(0.441)\end{array}$ & $\begin{array}{l}1.241^{* *} \\
(0.526)\end{array}$ & $\begin{array}{l}1.230^{* *} \\
(0.414)\end{array}$ & $\begin{array}{l}0.795^{* *} \\
(0.315)\end{array}$ & $\begin{array}{l}0.929^{* *} \\
(0.309)\end{array}$ & $\begin{array}{l}1.287^{* *} \\
(0.494)\end{array}$ & $\begin{array}{l}1.212^{* *} \\
(0.505)\end{array}$ & $\begin{array}{l}1.184^{* *} \\
(0.529)\end{array}$ & $\begin{array}{l}1.262^{* *} \\
(0.532)\end{array}$ \\
\hline Liquidity needs $\times$ Domestic debt $\times D_{d o m>60 \%}$ & $\begin{array}{c}-0.591^{*} \\
(0.320)\end{array}$ & $\begin{array}{c}-0.599^{*} \\
(0.327)\end{array}$ & $\begin{array}{l}-0.428 \\
(0.335)\end{array}$ & $\begin{array}{c}-0.598^{* *} \\
(0.234)\end{array}$ & $\begin{array}{l}-0.343 \\
(0.302)\end{array}$ & $\begin{array}{l}-0.395 \\
(0.328)\end{array}$ & $\begin{array}{c}-0.543^{*} \\
(0.316)\end{array}$ & $\begin{array}{c}-0.588^{* *} \\
(0.293)\end{array}$ & $\begin{array}{c}-0.591^{* *} \\
(0.299)\end{array}$ & $\begin{array}{c}-0.622^{* *} \\
(0.291)\end{array}$ \\
\hline Liquidity needs $\times$ Domestic debt $\times S_{\text {constr }}$ & $\begin{array}{c}0.442^{* *} \\
(0.146)\end{array}$ & $\begin{array}{l}0.307^{*} \\
(0.180)\end{array}$ & $\begin{array}{c}-0.273 \\
(0.293)\end{array}$ & $\begin{array}{c}0.122 \\
(0.299)\end{array}$ & & & & & & \\
\hline Liquidity needs $\times$ Domestic debt $\times S_{\text {short }}$ & & & & & $\begin{array}{c}0.183 \\
(0.164)\end{array}$ & $\begin{array}{l}-0.086 \\
(0.231)\end{array}$ & $\begin{array}{l}-0.310 \\
(0.233)\end{array}$ & & & \\
\hline Liquidity needs $\times$ Domestic debt $\times S_{\text {other }}$ & & & & & & & & $\begin{array}{c}0.042 \\
(0.347)\end{array}$ & $\begin{array}{c}0.012 \\
(0.173)\end{array}$ & $\begin{array}{c}-0.341^{*} \\
(0.339)\end{array}$ \\
\hline Initial industry share & Yes & Yes & Yes & Yes & Yes & Yes & Yes & Yes & Yes & Yes \\
\hline Fixed effects & Yes & Yes & Yes & Yes & Yes & Yes & Yes & Yes & Yes & Yes \\
\hline Observations & 899 & 899 & 899 & 839 & 589 & 589 & 899 & 899 & 899 & 868 \\
\hline Countries & 39 & 39 & 39 & 36 & 23 & 23 & 39 & 39 & 39 & 37 \\
\hline
\end{tabular}

Notes: All regressions include both industry and country fixed effects and a constant. The dependent variable is the annual compounded growth rate in real value added over the period 1990-2000 for each 3-digit ISIC industry in each country. The source of non-linearities associated with financial constraints $S_{\text {constr }}$ is a dummy variable taking the value of one in the following columns: (1) for industries above the median of the industry-specific measure of external finance dependence from Rajan and Zingales (1998), defined as the ratio of capital expenditures minus cash-flows from operations to capital expenditures; (2) for industries below the median of the industry-specific measure of assets pledgeability from Beutler and Grobéty (2011), based on the ease with which real assets are redeployed to alternative uses; (3) for countries below the median of the country-specific measure of private credit relative to GDP, where private credit is granted from deposit money banks and other financial institutions to the private sector; and (4) for countries below the median of the country-specific index of creditor rights from Djankov et al. (2007). The source of non-linearities associated with asset shortages $S_{\text {short }}$ is a dummy variable taking the value of one in the following columns: (5) for countries above the median of the global asset shortage that measures domestic capacity to generate private financial assets relative to gross national savings; (6) for countries above the median of the private asset shortage that measures domestic capacity to generate private and public financial assets relative gross national savings; and (7) for countries below the median of the financial openness index from Chinn and Ito (2006), which is based on the intensity of capital controls. The remaining sources of non-linearities $S_{\text {other }}$ are dummy variables taking the value of one in the following columns: (8) for high-income countries according to the World Bank classification; (9) for OECD countries; and (10) for countries below the median of the stock market turnover ratio defined as ratio of the value of total shares traded to average real market capitalization. The remaining variables are defined in Table 1. Columns (1)-(10) report the OLS estimates. Robust standard errors reported in parentheses are adjusted for two-way clustering at the industry and country level. **: significant at the $5 \%$ level. *: significant at the $10 \%$ level. 
Second, our instruments must be relevant (i.e., correlated with government debt). We use the Hansen $J$ test to check the statistical validity of the exclusion restrictions. In addition, we compute the Kleinbergen-Paap statistic to test the weak instrument assumption.

For comparison purposes, we estimate each baseline regression based on the same sample across both the OLS and IV estimation methods. ${ }^{20}$ OLS and IV estimates are reported in Table 3.

The IV estimates show that the main results of the paper remain unchanged and is not driven by reverse causality. The liquidity effect of total government debt on industry growth is positive and significant (columns (1) and (2) in Panel A). Furthermore, the IV estimates confirm that the liquidity channel of government debt operates only through the domestic supply of public liquidity (columns (3)-(8) in Panel B). In addition, we find that the IV and OLS estimates of the coefficient for the interaction term $L_{i} \times D D_{c}$ are of the same order of magnitude, whereas the IV estimates are lower than the OLS estimates (in absolute value) for total and external government debt. This suggests that the OLS estimate of the liquidity channel does not suffer from a serious bias.

Finally, the $p$-values of the Hansen $J$ test statistically confirm the validity of the exclusion restrictions in each IV regression. Furthermore, we strongly reject the weak instrument assumption according to the Kleinbergen-Paap statistics. ${ }^{21}$

\subsection{Testing for Competing Channels}

As noted above, the presence of fixed effects in the regression (1) mitigates the omitted variable bias. With fixed effects, the estimate of the coefficients $\beta$ and $\gamma$ is biased only if an omitted variable is correlated with both sectoral liquidity needs and government debt. Therefore, we estimate the baseline regression in column (4) of Table 1 by controlling for various competitive channels that may be correlated with the interaction terms of interest and industry growth.

\subsubsection{Channels Related to Financial Development and Openness}

The literature on the determinants of the size of government debt finds that countries with deeper financial systems tend to have larger domestic government bond markets (Claessens et al., 2007; Gennaioli et al., 2014). Without controlling for channels related to financial development, our estimate of the liquidity effect of government debt on industry growth may capture the effect of private liquidity provided by financial markets. Another competing channel that may bias

when we control for the liquidity effect of government debt. Furthermore, in a further robustness check, we find that our results are robust to controlling for the differential effect of government subsidies on industry growth (see column (1) of Table 5).

${ }^{20}$ Certain countries are removed from the sample because their government debt-to-GDP ratio in 1990 is not available.

${ }^{21}$ The Kleinbergen-Paap statistics are higher than the associated critical values for all regressions. The KleinbergenPaap statistic should be used when non-i.i.d errors are assumed, as in our case. However, its unknown critical values must be approximated using those of the Cragg-Donald statistic. The Cragg-Donald statistic has a known asymptotic distribution under the assumption of i.i.d errors. The null hypothesis of the weak instrument test is that the bias of the IV estimator, relative to the bias of OLS, exceeds the $5 \%$ threshold at the significance level of $5 \%$. The critical value of the Cragg-Donald statistic associated with this test is 16.85 (13.97) with 1 (2) endogenous regressor and 4 (5) instrumental variables as in regressions 2, 4 and 6 (8) of Table XX (see Stock and Yogo, 2002). 
TABLE 3

IV Estimates

\begin{tabular}{|c|c|c|c|c|c|c|c|c|}
\hline & OLS & IV & OLS & IV & OLS & IV & OLS & IV \\
\hline & (1) & (2) & (3) & (4) & (5) & (6) & (7) & (8) \\
\hline \multicolumn{9}{|l|}{ A. Total debt } \\
\hline $\begin{array}{l}\text { Liquidity needs } \times \text { Total debt } \\
\left(L_{i} \times T D_{c}\right)\end{array}$ & $\begin{array}{l}0.156^{* *} \\
(0.074)\end{array}$ & $\begin{array}{l}0.099^{*} \\
(0.057)\end{array}$ & & & & & & \\
\hline \multicolumn{9}{|c|}{ B. Domestic debt vs. External debt } \\
\hline $\begin{array}{l}\text { Liquidity needs } \times \text { Domestic debt } \\
\left(L_{i} \times D D_{c}\right)\end{array}$ & & & $\begin{array}{l}0.703^{* *} \\
(0.296)\end{array}$ & $\begin{array}{c}0.637^{* *} \\
(0.305)\end{array}$ & & & $\begin{array}{c}0.651^{* *} \\
(0.252)\end{array}$ & $\begin{array}{c}0.636^{* *} \\
(0.293)\end{array}$ \\
\hline $\begin{array}{l}\text { Liquidity needs } \times \text { External debt } \\
\left(L_{i} \times E D_{c}\right)\end{array}$ & & & & & $\begin{array}{l}-0.334 \\
(0.319)\end{array}$ & $\begin{array}{l}-0.237 \\
(0.248)\end{array}$ & $\begin{array}{l}-0.275 \\
(0.310)\end{array}$ & $\begin{array}{l}-0.143 \\
(0.221)\end{array}$ \\
\hline Initial industry share & Yes & Yes & Yes & Yes & Yes & Yes & Yes & Yes \\
\hline Fixed effects & Yes & Yes & Yes & Yes & Yes & Yes & Yes & Yes \\
\hline Hansen J test (p-value) & - & 0.323 & - & 0.446 & - & 0.377 & - & 0.461 \\
\hline Kleinbergen-Paap statistic & - & 35.39 & - & 125.5 & - & 95.63 & - & 53.12 \\
\hline Observations & 793 & 793 & 741 & 741 & 786 & 786 & 741 & 741 \\
\hline Countries & 34 & 34 & 32 & 32 & 34 & 34 & 32 & 32 \\
\hline
\end{tabular}

Notes: All regressions include both industry and country fixed effects and a constant. The dependent variable is the annual compounded growth rate in real value added over the period 1990-2000 for each 3-digit ISIC industry in each country. Odd columns report the OLS estimates. Even columns report IV estimates obtained by GMM with government debt instrumented by: (a) the initial government debt-to-GDP ratio in 1990; (b) the measure of the tax burden; (c) the measure of the extent of government spending. Instruments (b) and (c) were obtained from Gwartney et al. (2010) and are averaged over the period 1995-2000. The remaining variables are defined in Table 1. Robust standard errors reported in parentheses are adjusted for two-way clustering at the industry and country level. ${ }^{* *}$ : significant at the $5 \%$ level.

*: significant at the $10 \%$ level. 
TABLE 4

Controlling for Channels Related to Financial Development and Openness

\begin{tabular}{|c|c|c|c|c|c|c|c|c|c|c|c|c|}
\hline & (1) & (2) & (3) & (4) & (5) & (6) & (7) & $(8)$ & (9) & (10) & (11) & (12) \\
\hline $\begin{array}{l}\text { Liquidity needs } \times \text { Domestic debt } \\
\left(L_{i} \times D D_{c}\right)\end{array}$ & $\begin{array}{c}0.534^{* *} \\
(0.237)\end{array}$ & $\begin{array}{c}0.575^{* *} \\
(0.259)\end{array}$ & $\begin{array}{r}0.550^{* *} \\
(0.207)\end{array}$ & $\begin{array}{c}0.551^{* *} \\
(0.233)\end{array}$ & $\begin{array}{c}0.364^{* *} \\
(0.150)\end{array}$ & $\begin{array}{c}0.391^{* *} \\
(0.166)\end{array}$ & $\begin{array}{c}0.475^{* *} \\
(0.216)\end{array}$ & $\begin{array}{c}0.549^{* *} \\
(0.238)\end{array}$ & $\begin{array}{c}0.608^{* *} \\
(0.245)\end{array}$ & $\begin{array}{c}0.613^{* *} \\
(0.255)\end{array}$ & $\begin{array}{c}0.541^{* *} \\
(0.229)\end{array}$ & $\begin{array}{c}0.553^{* *} \\
(0.250)\end{array}$ \\
\hline $\begin{array}{l}\text { Liquidity needs } \times \text { External debt } \\
\left(L_{i} \times E D_{c}\right)\end{array}$ & $\begin{array}{l}-0.107 \\
(0.201)\end{array}$ & $\begin{array}{l}-0.074 \\
(0.214)\end{array}$ & $\begin{array}{l}-0.095 \\
(0.139)\end{array}$ & $\begin{array}{l}-0.088 \\
(0.144)\end{array}$ & $\begin{array}{c}0.017 \\
(0.369)\end{array}$ & $\begin{array}{l}-0.072 \\
(0.357)\end{array}$ & $\begin{array}{l}-0.037 \\
(0.174)\end{array}$ & $\begin{array}{l}-0.041 \\
(0.152)\end{array}$ & $\begin{array}{l}-0.006 \\
(0.204)\end{array}$ & $\begin{array}{l}-0.020 \\
(0.212)\end{array}$ & $\begin{array}{l}-0.122 \\
(0.198)\end{array}$ & $\begin{array}{l}-0.105 \\
(0.203)\end{array}$ \\
\hline Liquidity needs $\times$ Creditor rights & $\begin{array}{c}0.064^{* *} \\
(0.032)\end{array}$ & - & & & & & & & & & & \\
\hline Liquidity needs $\times$ Private credit & & & $\begin{array}{c}0.125 \\
(0.118)\end{array}$ & - & & & & & & & & \\
\hline Liquidity needs $\times$ Bond market capitalization & & & & & $\begin{array}{c}0.423 \\
(0.282)\end{array}$ & $\begin{array}{l}- \\
-\end{array}$ & & & & & & \\
\hline Liquidity needs $\times$ Stock market capitalization & & & & & & & $\begin{array}{c}0.161^{* * *} \\
(0.060)\end{array}$ & $\begin{array}{l}- \\
-\end{array}$ & & & & \\
\hline Liquidity needs $\times$ Stock market turnover & & & & & & & & & $\begin{array}{c}0.117 \\
(0.099)\end{array}$ & $\begin{array}{l}- \\
-\end{array}$ & & \\
\hline Liquidity needs $\times$ Financial openness & & & & & & & & & & & $\begin{array}{c}0.078^{* *} \\
(0.031)\end{array}$ & - \\
\hline$D_{i} \times F_{c}$ & No & Yes & No & Yes & No & Yes & No & Yes & No & Yes & No & Yes \\
\hline Initial industry share & Yes & Yes & Yes & Yes & Yes & Yes & Yes & Yes & Yes & Yes & Yes & Yes \\
\hline Fixed effects & Yes & Yes & Yes & Yes & Yes & Yes & Yes & Yes & Yes & Yes & Yes & Yes \\
\hline Observations & 839 & 839 & 899 & 899 & 589 & 589 & 868 & 868 & 868 & 868 & 899 & 899 \\
\hline Countries & 36 & 36 & 39 & 39 & 23 & 23 & 37 & 37 & 37 & 37 & 39 & 39 \\
\hline
\end{tabular}

Notes: All regressions include both industry and country fixed effects and a constant. The dependent variable is the annual compounded growth rate in real value added over the period 1990-2000 for each 3-digit ISIC industry in each country. $D_{i}$ is an industry dummy. The country-specific variables $F_{c}$ from Beck et al. (2010) (except Creditor rights and Financial openness) are averaged over the period 1991-2000 and are defined as follows: (a) Creditor rights refers to the creditor rights index from Djankov et al. (2007); (b) Private credit is defined as the credit by deposit money banks and other financial institutions to the private sector divided by GDP; (c) Bond market capitalization is the ratio of the total amount of outstanding domestic debt securities issued by private domestic entities to GDP; (d) Stock market capitalization is the ratio of the value of listed shares to GDP; (e) Stock market turnover is the ratio of the value of total shares traded to average real market capitalization; and (f) Financial openness is the index from Chinn and Ito (2006) that measures the intensity of capital controls. The remaining variables are defined in Table 1. Columns (1)-(12) report the OLS estimates. Robust standard errors reported in parentheses are adjusted for two-way clustering at the industry and country level. **: significant at the $5 \%$ level. *: significant at the $10 \%$ level. 
our baseline results is related to the degree of financial openness. We carefully control for the growth effect of private liquidity facilitated by financial development and openness by including an interaction of industry's liquidity needs with the country's financial development and openness $\left(L_{i} \times F_{c}\right)$ as controls in our baseline regression (1). In addition, we control for the entire differential effect of financial development and openness on industry growth by adding the interaction of an industry dummy with a country-specific indicator of private liquidity $\left(D_{i} \times F_{c}\right)$. In columns (1)-(10) of Table 4, financial development is measured by creditor rights from Djankov et al. (2007), the ratio of private credit to GDP, bond and stock market capitalization relative to GDP, and stock market turnover. In columns (11)-(12), financial openness corresponds to the index from Chinn and Ito (2006) that measures the intensity of capital controls.

The estimation results in Table 4 show that the baseline results of the paper remain qualitatively and quantitatively unaffected by controlling for channels related to financial development and openness. Overall, these controls do not change either the magnitude or the significance of the estimate of the coefficient for the main variable of interest $L_{i} \times D D_{c}$. This holds true even in regressions that include the interaction term $D_{i} \times F_{c}$. Furthermore, the interaction of liquidity needs with external government debt as placebo liquidity remains insignificant in all the regressions in Table 4.

\subsubsection{Alternative Channels}

In addition to private liquidity provided by financial markets, sectoral growth can be affected by alternative channels that may drive the positive liquidity effect of government debt on industry growth. In Table 6, we study four alternative channels. The first alternative channel we consider is the possibility that governments issue more domestic debt to subsidize sectors with high liquidity needs, which boosts their economic performance. In column (1) we control for the effect of government subsidies on industry growth in an unrestricted manner by interacting them with an industry dummy. The subsidy channel does not change the baseline results of the paper. The main variable of interest $L_{i} \times D D_{c}$ maintains a positive and significant coefficient, while the interaction term $L_{i} \times E D_{c}$ remains insignificant.

Second, industries with greater liquidity needs are also likely to produce complex goods. Because the production of complex goods requires an increasing number of tasks to be performed, these sectors may have longer cash conversion cycles but are also more dependent on stable institutions for growth (Berkowitz et al., 2006; Levchenko, 2007). Moreover, the quality of institutions is found to be a relevant factor for countries to develop their domestic government debt markets (Burger and Warnock, 2003; Chamon et al., 2005; Claessens et al., 2007). The liquidity channel of the government may be driven by the quality of institutions because the latter is found to be a relevant factor for countries to develop their domestic government debt markets (Burger and Warnock, 2003; Chamon et al., 2005; Claessens et al., 2007). Moreover, industries with high liquidity needs may require more skilled labor; the supply of skilled labor is positively correlated with the quality of institutions from a cross-country perspective. We rely on the industry-specific characteristics 
TABLE 5

Testing for Alternative Channels

\begin{tabular}{|c|c|c|c|c|c|c|c|}
\hline & (1) & (2) & (3) & $(4)$ & (5) & (6) & (7) \\
\hline $\begin{array}{l}\text { Liquidity needs } \times \text { Domestic debt } \\
\left(L_{i} \times D D_{c}\right)\end{array}$ & $\begin{array}{c}0.634^{* *} \\
(0.265)\end{array}$ & $\begin{array}{c}0.605^{* *} \\
(0.229)\end{array}$ & $\begin{array}{c}0.641^{* *} \\
(0.325)\end{array}$ & $\begin{array}{c}0.572^{* *} \\
(0.258)\end{array}$ & $\begin{array}{c}0.601^{* *} \\
(0.238)\end{array}$ & $\begin{array}{c}0.533^{* *} \\
(0.209)\end{array}$ & $\begin{array}{r}0.698^{* *} \\
(0.267)\end{array}$ \\
\hline $\begin{array}{l}\text { Liquidity needs } \times \text { External debt } \\
\left(L_{i} \times E D_{c}\right)\end{array}$ & $\begin{array}{l}-0.103 \\
(0.180)\end{array}$ & $\begin{array}{l}-0.170 \\
(0.181)\end{array}$ & $\begin{array}{l}-0.103 \\
(0.159)\end{array}$ & $\begin{array}{l}-0.085 \\
(0.144)\end{array}$ & $\begin{array}{l}-0.260 \\
(0.254)\end{array}$ & $\begin{array}{l}-0.112 \\
(0.137)\end{array}$ & $\begin{array}{l}-0.197 \\
(0.246)\end{array}$ \\
\hline Industry dummy $\times$ Subsidies & $\begin{array}{l}- \\
-\end{array}$ & & & & & & \\
\hline Contract intensity $\times$ Rule of law & & $\begin{array}{c}0.003 \\
(0.020)\end{array}$ & & & & & \\
\hline Skill intensity $\times$ Human capital & & & $\begin{array}{c}0.031^{* *} \\
(0.015)\end{array}$ & & & & \\
\hline Industry dummy $\times$ Economic development & & & & $\begin{array}{l}- \\
-\end{array}$ & & & \\
\hline Liquidity needs $\times$ Reserve money & & & & & $\begin{array}{c}0.535 \\
(0.651)\end{array}$ & & \\
\hline Liquidity needs $\times$ Cash & & & & & & $\begin{array}{c}0.181 \\
(0.193)\end{array}$ & \\
\hline Growth opportunities $\times$ Domestic debt & & & & & & & $\begin{array}{l}0.740^{* *} \\
(0.347)\end{array}$ \\
\hline Initial industry share & Yes & Yes & Yes & Yes & Yes & Yes & Yes \\
\hline Fixed effects & Yes & Yes & Yes & Yes & Yes & Yes & Yes \\
\hline Observations & 878 & 899 & 817 & 899 & 883 & 899 & 853 \\
\hline Countries & 38 & 39 & 35 & 39 & 38 & 39 & 39 \\
\hline
\end{tabular}

Notes: All regressions include both industry and country fixed effects and a constant. The dependent variable is the annual compounded growth rate in real value added over the period 1990-2000 for each 3-digit ISIC industry in each country. The industry-specific variables, which are constructed using U.S. data, include the following: (i) Contract intensity from Levchenko (2010) reports the industry share of intermediate inputs that cannot be purchased on organized exchanges and is not reference-priced; (ii) Skill intensity, computed by Braun (2005), is the mean wage for each 3-digit ISIC U.S. manufacturing sector; and (iii) Growth opportunities measures the annual compounded growth rate for each 3-digit ISIC industry real value added in the U.S, over the period 1990-2000. The country-specific variables include the following: (a) Subsidies from the 2010 Economic Freedom Dataset measures the average share of general government transfers and subsidies as a share in GDP for 1990, 1995 and 2000; (b) Rule of law is from Kaufmann et al. (2009) and measures the extent to which agents have confidence in and abide by the rules of society in 1996; (c) Human capital is the average years of schooling over the period 1991-2000; (d) Economic development is defined as the log of the mean of real GDP per capita during the 1980's; (e) Reserve money from IFS is the average monetary base over the period 1991-2000; and (f) Cash from IFS is measured by the average cash obtained by the private sector from the central bank over the period 1991-2000. The remaining variables are defined in Table 1. Columns (1)-(7) report the OLS estimates. Robust standard errors reported in parentheses are adjusted for two-way clustering at the industry and country level. **: significant at the $5 \%$ level. *: significant at the $10 \%$ level. 
from Braun (2005) to measure the intensity of skilled workers and from Levchenko (2010) to proxy contract intensity. In columns (2) and (3), we include the interaction of these industry-specific characteristics with the index of the rule of law used as a proxy for the quality of contracting institutions. In column (4), we control for the effect of institutional and economic development by including the interaction of an industry dummy with initial GDP per capita. The presence of these alternative channels does not affect the baseline results of the paper.

Third, money represents an alternative store of value and hence may be a close substitute to government bonds. Therefore, the relative better performance of sectors with high liquidity needs may be attributed to the monetization of domestic government debt. This channel is accounted for by including the interaction of liquidity needs with the money supply. We use two measures of the money supply: the quantity of cash supplied by the central bank to the domestic private sector and the amount of reserve money available at the country-wide level. Both controls enter the regressions in columns (5) and (6) with the positive expected sign but are statistically insignificant. However, the liquidity effect of government debt on growth remains unchanged in both quantitative and statistical terms.

Finally, in column (7) of Table 6, we control for industry growth opportunities. The empirical literature on corporate cash holdings provides evidence that firms with better investment opportunities hold more liquid assets (see e.g. Opler et al., 1999). We explore a competing channel as in Woodford (1990). If sectors with high liquidity needs also have the best growth outlook, they will grow relatively faster in countries with more domestic government debt because investment in government bonds facilitates investment in future opportunities. We follow Fisman and Love (2007) by using sectoral growth in the U.S. economy as a proxy for global investment opportunities. While the interaction of growth opportunities with domestic government debt is significant and enters the regression in column (7) with the positive expected sign, our main variable of interest $L_{i} \times D D_{c}$ remains positive and significant.

\subsection{Sensitivity Analysis}

We now test the sensitivity of our baseline results in Table 6 . 
TABLE 6

SENSITIVITY ANALYSIS

\begin{tabular}{|c|c|c|c|c|c|c|c|}
\hline & $\begin{array}{l}\text { Cash conv. } \\
\text { cycle }\end{array}$ & $\begin{array}{l}\text { Investment } \\
\text { lumpiness }\end{array}$ & $\mathrm{R} \& \mathrm{D}$ intensity & Public bond & $\begin{array}{c}\text { Investment } \\
\text { share }\end{array}$ & Output growth & $\begin{array}{l}\text { Productivity } \\
\text { growth }\end{array}$ \\
\hline & (1) & (2) & (3) & (4) & (5) & (6) & (7) \\
\hline $\begin{array}{l}\text { Liquidity needs } \times \text { Domestic debt } \\
\left(L_{i} \times D D_{c}\right)\end{array}$ & $\begin{array}{l}0.097^{* *} \\
(0.044)\end{array}$ & $\begin{array}{l}0.061^{* *} \\
(0.025)\end{array}$ & $\begin{array}{l}0.083^{* *} \\
(0.040)\end{array}$ & $\begin{array}{l}0.517^{* *} \\
(0.240)\end{array}$ & $\begin{array}{l}0.574^{*} \\
(0.315)\end{array}$ & $\begin{array}{l}0.433^{* *} \\
(0.181)\end{array}$ & $\begin{array}{l}0.451^{* *} \\
(0.197)\end{array}$ \\
\hline $\begin{array}{l}\text { Liquidity needs } \times \text { External debt } \\
\left(L_{i} \times E D_{c}\right)\end{array}$ & $\begin{array}{l}-0.029 \\
(0.041)\end{array}$ & $\begin{array}{l}-0.015 \\
(0.019)\end{array}$ & $\begin{array}{l}-0.014 \\
(0.020)\end{array}$ & $\begin{array}{l}- \\
-\end{array}$ & $\begin{array}{l}-0.201 \\
(0.168)\end{array}$ & $\begin{array}{l}-0.081 \\
(0.210)\end{array}$ & $\begin{array}{l}-0.077 \\
(0.142)\end{array}$ \\
\hline Initial industry share & Yes & Yes & Yes & Yes & No & Yes & Yes \\
\hline Fixed effects & Yes & Yes & Yes & Yes & Yes & Yes & Yes \\
\hline Observations & 899 & 899 & 899 & 646 & 815 & 892 & 878 \\
\hline \multirow[t]{3}{*}{ Countries } & 39 & 39 & 39 & 26 & 36 & 39 & 39 \\
\hline & Period $80-00$ & $\begin{array}{l}\text { Dropping } 1 \% \\
\text { outliers }\end{array}$ & $\begin{array}{l}\text { Dropping } 5 \% \\
\text { outliers }\end{array}$ & $\begin{array}{c}\text { Dropping } \\
\text { countries } \\
\text { sectors }<20\end{array}$ & DFBETA & $\begin{array}{l}\text { Robust } \\
\text { regression }\end{array}$ & \\
\hline & (8) & (9) & (10) & (11) & (12) & (13) & \\
\hline $\begin{array}{l}\text { Liquidity needs } \times \text { Domestic debt } \\
\left(L_{i} \times D D_{c}\right)\end{array}$ & $\begin{array}{c}0.249^{* *} \\
(0.126)\end{array}$ & $\begin{array}{c}0.458^{* *} \\
(0.193)\end{array}$ & $\begin{array}{c}0.245^{* *} \\
(0.106)\end{array}$ & $\begin{array}{c}0.626^{* *} \\
(0.228)\end{array}$ & $\begin{array}{c}0.710^{* *} \\
(0.236)\end{array}$ & $\begin{array}{c}0.401^{* *} \\
(0.168)\end{array}$ & \\
\hline $\begin{array}{l}\text { Liquidity needs } \times \text { External debt } \\
\left(L_{i} \times E D_{c}\right)\end{array}$ & $\begin{array}{l}-0.045 \\
(0.129)\end{array}$ & $\begin{array}{c}0.013 \\
(0.138)\end{array}$ & $\begin{array}{c}0.029 \\
(0.056)\end{array}$ & $\begin{array}{l}-0.102 \\
(0.274)\end{array}$ & $\begin{array}{l}-0.157 \\
(0.184)\end{array}$ & $\begin{array}{c}0.048 \\
(0.155)\end{array}$ & \\
\hline Initial industry share & Yes & Yes & Yes & Yes & Yes & Yes & \\
\hline Fixed effects & Yes & Yes & Yes & Yes & Yes & Yes & \\
\hline Observations & 900 & 881 & 809 & 782 & 854 & 899 & \\
\hline Countries & 39 & 39 & 39 & 31 & 39 & 39 & \\
\hline
\end{tabular}

Notes: All regressions include both industry and country fixed effects and a constant. The dependent variable is the annual compounded industry growth rate: (i) in real value added over the period 1990-2000 in columns (1)-(4) and (9)-(13), and over the period 1980-2000 in column (8); (ii) in real output over the period 1990-2000 in column (6); and (iii) in real value added per worker over the period 1990-2000 in column (3). In column (5), we use the share of industry investment to total investment at the country level over the period 1990-2000 as the dependent variable. Sectoral liquidity needs is measured by the following: (i) the ratio of inventories to sales from Raddatz (2006) in columns (4)-(13); (ii) the average number of days between a firm's payment for its inputs and the sale of output from Raddatz (2006) in column (1); (iii) the average number of investment spikes from Ilyina and Samaniego (2011) in column (2), where a spike is an annual capital expenditure in excess of $30 \%$ of the firmâs fixed assets; and (iv) the ratio of R\&D expenditures over capital expenditures computed by Ilyina and Samaniego (2011) in column (3). Government debt is measured by the following: (i) the ratio of domestic or government debt to GDP averaged over the period 1991-2000 in columns (1)-(3) and (5)-(13) (data were obtained from Panizza (2008)) and (ii) the ratio of domestic marketable securities issued by public domestic entities to GDP averaged over the period 1991-2000 in column (4) (data were obtained from Beck et al. (2010)). **: significant at the $5 \%$ level. *: significant at the $10 \%$ level. 
In columns (1)-(3) of Table 6 , we test whether our baseline results remain robust to the use of alternative industry-specific motives for liquidity needs. First, we use the length of the cash conversion cycle as an alternative proxy for the asynchronicity between the need for and access to liquidity. This proxy measures the average number of days between a firm's payment for its inputs and the sale of output. In addition, we consider investment lumpiness as a source of mismatch between investment spending and cash flow. Investment lumpiness measures the frequency of "spikes" in firm-level investment. In addition, sectors must save liquid assets for precautionary motives. Bates et al. (2009) document that U.S. firms increase their R\&D expenditures from 1980 to 2006 and hoard more liquid assets because investment in R\&D is inherently risky. In line with this finding, we use sectoral R\&D intensity as an alternative motive for liquidity needs in column (3). Our variable of interest, $L_{i} \times D D_{c}$, turns out to be positive and statistically significant irrespective of the motive of liquidity needs, while the interaction term $L_{i} \times E D_{c}$ associated with the placebo component of government debt remains insignificant.

In column (4), we use a direct measure of public liquidity. We consider the average ratio of public bond market capitalization to GDP over the period 1991-2000. Although the number of countries is reduced from 39 to 26 , the estimated coefficient on the interaction term, $L_{i} \times D D_{c}$, has the expected positive sign and remains significant at the $5 \%$ level. In columns (5)-(8), we test the sensitivity of our baseline results to alternative measures of the dependent variable for the period 1990-2000. We use the investment share in column (5), output growth in column (6) and productivity growth in column (7). Then, we consider a longer time span and compute industry growth in real value added over the period 1980-2000 in column (8). In each of these regressions, our baseline results remain unaltered.

In columns (9)-(11), we investigate whether the positive and significant liquidity effect of government debt on industry growth is driven by the presence of outliers. We remove observations below the 1st (5th) and above the 99th (95th) percentile of the industry growth distribution in column (9) (column (10)) and we remove countries for which data on industry growth are available for less than 20 sectors in column (11). Our baseline results remain basically unaffected by these exclusions. $^{22}$ Then, we check the sensitivity of our baseline results to the presence of influential observations. In column (11), influential observations are detected by computing the DFBETA statistic. This statistic measures the change in the estimated coefficient for the interaction term $L_{i} \times D D_{c}$ with and without a particular observation. We identify 45 influential observations using the conventional cutoff and drop them in column (11). ${ }^{23}$ The liquidity effect of government debt on industry growth becomes slightly larger than in the baseline regression and remains highly

\footnotetext{
${ }^{22}$ In the Web Appendix, we estimate our baseline regression in column (4) of Table 1 by excluding each country and industry from the baseline regression sample. We show that the baseline results of the paper is not driven by a specific country nor by a specific industry.

${ }^{23}$ The conventional cutoff is $2 / \sqrt{N}$ where $N$ represents the number of observations. An observation $j$ is considered influential if $\left|D F B E T A_{j}\right|>2 / \sqrt{N}$. On average, 1.15 observations per country were dropped from the sample, whereas 4.50 observations per country with a level of domestic debt above 60 percent of GDP are considered influential (Chile: 2, Singapore: 5, Italy: 6, and Israel: 5). This is not the case for countries with a high level of external government debt (Panama: 1, Senegal: 0, and Jordan: 0). This can be interpreted as further evidence that only high levels of domestic debt significantly change the magnitude of the liquidity channel of government debt.
} 
significant. ${ }^{24}$ Then, a robust treatment of outliers is performed in column (12) using the robust regression procedure implemented in Stata. ${ }^{25}$ The liquidity channel of government debt decreases in magnitude with respect to the baseline regression, but remains significant at the $5 \%$ level.

\section{Conclusion}

An influential strand of theoretical literature suggests that government debt is detrimental to long-run economic growth. Another strand of literature argues that government debt can foster growth by enhancing the supply of liquid assets or collateral. This is the liquidity channel of government debt through which government debt facilitates private investment by relaxing financial constraints, and thereby can enhance growth. This paper empirically investigates the liquidity channel of government debt. Following the methodology of Rajan and Zingales (1998), we focus on an interaction term between sectoral liquidity needs based on U.S. data and levels of government debt, and estimate the effect of this interaction on long-run industry growth. This methodology helps to address potential endogeneity problems arising from a cross-country analysis and allows us to identify the causal effect of liquidity-enhancing government debt on growth. We provide evidence that industries with greater liquidity needs tend to grow disproportionately faster in countries with higher levels of government debt. The positive liquidity effect of government debt on industry growth stems from domestic debt, not external debt. We perform a battery of robustness checks and show that our results are robust to using instrumental variables and controlling for many competing channels.

The results of this paper suggest the following policy recommendation for debt management. Governments should implement policies aimed at reducing the issuance of external debt and substituting it with domestic debt. This recommendation appears to be consistent with recent trends in the composition of government debt. Over the period 1990-2010, domestic debt accounts for an increasing share of total government debt in both developing and developed countries (Forslund et al., 2011; Reinhart and Rogoff, 2011a). This policy tends to promote economic growth through the liquidity channel. However, government debt can either boost or hinder economic performance through other channels. Empirically identifying these channels remains an area for future research and will contribute to our understanding of the debt-growth nexus.

\footnotetext{
${ }^{24}$ If the DFBETA statistic for $L_{i} \times E D_{c}$ is computed, similar qualitative results are obtained (not reported).

${ }^{25}$ The robust regression (rreg command in Stata) is an iterative two-step procedure that aims at mitigating the effect of outliers. First residuals are estimated using the OLS coefficient estimates. Then, it assigns smaller weights to observations with larger residuals and runs a second OLS regression. This two-step procedure is run until the difference in weights approaches zero.
} 


\section{Appendix}

\section{A Sources and Description of Data}

Government Debt and Bonds. Data on total, domestic and external government debt-to-GDP ratios are obtained from Panizza (2008). The dataset relies on several publicly available sources and includes central government debt of up to 130 countries for the period 1990-2007. Domestic and external government debt are reported in billions of U.S. dollars. Domestic government debt is the amount of public debt issued by country $c$ in country $c$ and under country $c$ 's jurisdiction. External government debt is the amount of public debt issued by country $c$ in foreign countries and regulated by foreign law. Total government debt is the sum of domestic and external government debt. Data on GDP in billions of current U.S. dollars also provided by Panizza were obtained from the World Development Indicators (WDI). The supply of government bonds is measured as the ratio of domestic marketable securities issued by public domestic entities to GDP. This indicator was used in Beck et al. (2010); however, original data are collected by the Bank for International Settlements (BIS, 2009) from market and institutional sources. Each ratio is averaged over the period 1991-2000.

Industry Liquidity Needs and Financial Constraints. Industry-specific indicators of liquidity needs and financial constraints are computed using U.S. firm-level data for each 3-digit ISIC industry. The proxy for sectoral dependence on liquidity is the measure of Liquidity needs originally constructed by Raddatz (2006). This proxy is defined as the median ratio of total inventories over annual sales for U.S. manufacturing firms in each four-digit ISIC industry over the period 1980-89. We use the measure of sector-specific liquidity needs converted by Aghion et al. (2009) at the three-digit ISIC level (see Table A11 in their appendix).

Cash conversion cycle is computed by Raddatz (2006) as 365× [(inventories-account payable)/cost of good sold] $+365 \times$ (account receivables/sales) for each four-digit ISIC industry. We obtain a measure at the three-digit ISIC level by averaging the cash conversion cycle of four-digit sectors that are a subset of each three-digit sector. Investment lumpiness from Ilyina and Samaniego (2011) is the average number of investment spikes, where a spike is an annual capital expenditure in excess of $30 \%$ of the firm's fixed assets. RED intensity is computed by Ilyina and Samaniego (2011) as the ratio of $\mathrm{R} \& \mathrm{D}$ expenditures over capital expenditures. Tangibility from Braun and Larrain (2005) measures the tangibility of assets and is defined the median ratio of net property, plant and equipment to total assets for U.S. firms in each industry over the period 1986-95. External financial dependence from Rajan and Zingales (1998) is defined as the industry-specific ratio of capital expenditures minus cash-flows from operations to capital expenditures. Assets pledgeability is an industry-specific measure of real assets' redeployability developed by Beutler and Grobéty (2011), which captures the ease with which real assets used by firms in an industry are transferred to alternative uses. 
TABLE A.1

Liquidity Needs and Cash Conversion Cycle

\begin{tabular}{|c|c|c|c|}
\hline ISIC & Industrial sector & Liquidity needs & $\begin{array}{c}\text { Cash conversion } \\
\text { cycle }\end{array}$ \\
\hline 353 & Petroleum refineries & 0.06 & 0.19 \\
\hline 342 & Printing and publishing & 0.08 & 0.78 \\
\hline 313 & Beverages & 0.09 & 0.68 \\
\hline 311 & Food products & 0.11 & 0.61 \\
\hline 341 & Paper and products & 0.11 & 0.75 \\
\hline 331 & Wood products, except furniture & 0.13 & 0.78 \\
\hline 351 & Industrial chemicals & 0.13 & 0.88 \\
\hline 355 & Rubber products & 0.14 & 0.93 \\
\hline 356 & Plastic products & 0.14 & 0.84 \\
\hline 352 & Other chemicals & 0.15 & 1.05 \\
\hline 369 & Other non-metallic products & 0.15 & 1.00 \\
\hline 354 & Miscellaneous petroleum and coal products & 0.15 & 0.69 \\
\hline 372 & Non-ferrous metals & 0.15 & 0.88 \\
\hline 384 & Transport equipment & 0.15 & 0.88 \\
\hline 362 & Glass and products & 0.16 & 0.96 \\
\hline 321 & Textiles & 0.16 & 0.99 \\
\hline 332 & Furniture, except metal & 0.16 & 1.07 \\
\hline 371 & Iron and steel & 0.16 & 0.90 \\
\hline 361 & Pottery, china, earthenware & 0.17 & 1.23 \\
\hline 381 & Fabricated metal products & 0.18 & 1.13 \\
\hline 322 & Wearing apparel, except footwear & 0.20 & 1.23 \\
\hline 390 & Other manufactured products & 0.21 & 1.64 \\
\hline 383 & Machinery, electric & 0.21 & 1.41 \\
\hline 382 & Machinery, except electrical & 0.21 & 1.43 \\
\hline 385 & Professional and scientific equipment & 0.22 & 1.60 \\
\hline 324 & Footwear, except rubber or plastic & 0.22 & 1.33 \\
\hline 314 & Tobacco & 0.24 & 1.40 \\
\hline 323 & Leather products & 0.27 & 1.57 \\
\hline \multicolumn{2}{|l|}{ Mean } & 0.16 & 1.03 \\
\hline \multicolumn{2}{|c|}{ Correlation } & & 0.92 \\
\hline
\end{tabular}

TABLE A.2

Correlations with Liquidity NeEdS

\begin{tabular}{|c|c|c|c|c|c|c|c|}
\hline Correlation & $\begin{array}{l}\text { Liquidity } \\
\text { needs }\end{array}$ & Tangibility & $\begin{array}{l}\text { External } \\
\text { finance } \\
\text { dependance }\end{array}$ & $\begin{array}{c}\text { Assets } \\
\text { pledgeabil- } \\
\text { ity }\end{array}$ & $\begin{array}{c}\text { Cash } \\
\text { conversion } \\
\text { cycle }\end{array}$ & $\begin{array}{l}\text { Investment } \\
\text { lumpiness }\end{array}$ & $\begin{array}{c}\text { R\&D } \\
\text { intensity }\end{array}$ \\
\hline Liquidity needs & 1.00 & & & & & & \\
\hline Tangibility & -0.74 & 1.00 & & & & & \\
\hline External finance dependance & 0.00 & -0.07 & 1.00 & & & & \\
\hline Assets pledgeability & 0.13 & -0.20 & -0.33 & 1.00 & & & \\
\hline Cash conversion cycle & 0.92 & -0.80 & 0.12 & 0.07 & 1.00 & & \\
\hline Investment lumpiness & 0.41 & -0.56 & 0.68 & -0.17 & 0.54 & 1.00 & \\
\hline R\&D intensity & 0.39 & -0.41 & 0.59 & -0.25 & 0.49 & 0.68 & 1.00 \\
\hline
\end{tabular}

Growth at the Industry Level. Growth at the industry level is measured using production data provided by Nicita and Olarreaga (2007) for 28 manufacturing sectors over the period 1976-2004. The data are originally from the United Nations Industrial Development Organization (UNIDO) 
and are reported according to the 3-digit ISIC Rev. 2 classification. Value added is reported by UNIDO in thousand current US dollars. We divide value added by $\left[\left(C G D P_{c t} / R G D P_{c t}\right)\right] \times$ $\left(P_{c t} / 100\right)$ to express value added in constant international dollars for industry $i$ in country $c$ at year $t\left(v a_{i c t}\right)$. This deflation procedure is from Levchenko et al. (2009). Data on per capita nominal GDP $\left(C G D P_{c t}\right)$ and real GDP $\left(R G D P_{c t}\right)$ in international dollars, on the price level of GDP $\left(P_{c t}\right)$ and on population $\left(P O P_{c t}\right.$, in thousands) are obtained from the Penn World Table (Heston et al. (2006)). Real growth in value added is the annual compounded growth rate in real value added of industry $i$ in country $c$ over the period 1990-2000 $\left[g_{i c}=\left(\log v a_{i c, 2000}-\log v a_{i c, 1990}\right) / 10\right]$.

For the sensitivity analysis, we use data on the number of employees and output, which represents the value of goods produced in a year, whether sold or stocked; these data are obtained from the UNIDO database. We apply the same transformations as for value added to obtain output in constant international dollars. Output growth is the annual compounded growth rate for the output of industry $i$ in country $c$ over the period 1990-2000. Likewise, productivity growth is the annual compounded growth rate in labor productivity of industry $i$ in country $c$ over the period 1990-2000, where labor productivity is defined as the real value added per employee.

Initial industry share. The Initial industry share is computed using the UNIDO dataset from Nicita and Olarreaga (2007) and defined as the share of the industry $i$ 's real value added to the country c's total manufacturing real value added in $1990\left(v a_{i c, 1990} / \sum_{i=1}^{28} v a_{i c, 1990}\right)$. 


\section{B Sample}

TABle A.3

Country Sample

\begin{tabular}{|c|c|c|c|}
\hline Country & $\begin{array}{c}\text { Number of } \\
\text { sectors }\end{array}$ & Country & $\begin{array}{c}\text { Number of } \\
\text { sectors }\end{array}$ \\
\hline Australia & 20 & Republic of Korea & 28 \\
\hline Austria & 22 & Malaysia & 26 \\
\hline Bolivia $^{c}$ & 26 & Malta & 17 \\
\hline Canada & 27 & Mexico $^{c}$ & 26 \\
\hline Chile $^{a, b, c}$ & 28 & Morocco $^{b, c}$ & 12 \\
\hline Colombia & 25 & Netherlands & 26 \\
\hline Costa Rica $^{c}$ & 22 & Norway & 26 \\
\hline Cyprus & 25 & Panama $a^{b, c}$ & 16 \\
\hline Ethiopia $^{b}$ & 21 & Poland $^{c}$ & 10 \\
\hline Finland $^{b}$ & 26 & Senegal ${ }^{b, c}$ & 10 \\
\hline France & 23 & Singapore ${ }^{a, b}$ & 21 \\
\hline Hungary $^{b}$ & 26 & Spain & 27 \\
\hline India & 28 & Sri Lanka ${ }^{b}$ & 26 \\
\hline Indonesia $^{b}$ & 24 & Sweden $^{b}$ & 28 \\
\hline Ireland & 26 & Trinidad \& Tobago & 18 \\
\hline Israel $^{a, b}$ & 17 & Tunisia & 17 \\
\hline Italy $^{a, b}$ & 26 & Turkey & 26 \\
\hline Japan & 28 & United Kingdom & 26 \\
\hline Jordan $^{b, c}$ & 27 & Uruguay $^{c}$ & 21 \\
\hline Kenya & 25 & Portugal & 26 \\
\hline
\end{tabular}

Notes: This table displays each country included in the baseline regression sample. The exponent $a$ (b) denotes countries with average domestic (total) government-to-GDP ratios over the period 1991-2000 above $60 \%$. The exponent $c$ denotes countries that experienced an episode of sovereign debt default and restructuring during the 1990's following Laeven and Valencia (2013). 


\section{Summary Statistics}

TABLE A.4

Summary Statistics

\begin{tabular}{lccccc}
\hline & Mean & Std. dev. & Min. & Max. & Obs. \\
\hline Industry-country-specific variables & & & & & \\
\hline Real growth rate of value added (1990-2000) & 0.0186 & 0.0729 & -0.4803 & 0.3244 & 899 \\
Liquidity needs × Total debt & 0.0906 & 0.0487 & 0.0071 & 0.2878 & 899 \\
Liquidity needs × Domestic debt & 0.0531 & 0.0367 & 0.0027 & 0.2331 & 899 \\
Liquidity needs × External debt & 0.0384 & 0.0362 & 0 & 0.2599 & 899 \\
Tangibiliy × Domestic debt & 0.0944 & 0.0725 & 0.0041 & 0.4817 & 899 \\
Initial industry share & -3.8636 & 1.2933 & -9.5784 & -0.6452 & 899 \\
\hline Country-specific variables & & & & & \\
\hline Mean total debt to GDP (1991-2000) & 0.5840 & 0.2608 & 0.1408 & 1.1824 & 39 \\
Mean domestic debt to GDP (1991-2000) & 0.3206 & 0.1985 & 0.0448 & 0.8635 & 39 \\
Mean external debt to GDP (1991-2000) & 0.2539 & 0.2166 & 0.0001 & 0.9624 & 39 \\
Creditor rights & 1.95 & 1.1956 & 0 & 4 & 36 \\
Private credit to GDP & 0.6521 & 0.3989 & 0.1352 & 1.8424 & 39 \\
Financial openness & 0.7672 & 1.4051 & -1.4443 & 2.5318 & 39 \\
Initial total debt to GDP (1990) & 0.6227 & 0.4326 & 0.0634 & 2.0617 & 34 \\
Initial domestic debt to GDP (1990) & 0.3485 & 0.2725 & 0 & 1.1507 & 32 \\
Initial external debt to GDP (1990) & 0.2859 & 0.3495 & 0.0011 & 1.6772 & 34 \\
Government spending & 57.8559 & 28.2187 & 0 & 92.3000 & 34 \\
Fiscal freedom & 62.8588 & 15.279 & 34.1 & 89 & 34 \\
Monetary freedom & 79.3235 & 11.1277 & 31.8 & 94.2 & 34 \\
\hline Industry-specific variables & & & & & \\
\hline Liquidity needs & 0.1611 & 0.0489 & 0.06 & 0.27 & 28 \\
Tangibiliy & 0.2977 & 0.1392 & 0.0745 & 0.6708 & 28 \\
Cash conversion cycle & 1.0309 & 0.3374 & 0.19 & 1.6425 & 28 \\
External finance dependence & 0.2686 & 0.3586 & -0.45 & 1.14 & 28 \\
R\&D intensity & 0.2844 & 0.3534 & 0 & 1.369 & 28 \\
Human capital intensity & 2.1891 & 0.5813 & 1.093 & 3.493 & 28 \\
Investment lumpiness & 1.591 & 0.6228 & 0.546 & 2.961 & 28 \\
Real assets' pledgeability & 0.7458 & 0.0625 & 0.6502 & 0.8939 & 28 \\
\hline
\end{tabular}




\section{References}

Aghion, P., G. Angeletos, A. Banerjee, And K. Manova (2010): "Volatility and growth: Credit constraints and the composition of investment," Journal of Monetary Economics, 57, 246-265.

Aghion, P., P. Bacchetta, R. Rancière, and K. Rogoff (2009): "Exchange rate volatility and productivity growth: The role of financial development," Journal of Monetary Economics, $56,494-513$.

Aiyagari, S. And E. McGrattan (1998): "The optimum quantity of debt," Journal of Monetary Economics, 42, 447-469.

Angeletos, G.-M., F. Collard, and H. Dellas (2016): "Public Debt as Private Liquidity: Optimal Policy," NBER Working Paper.

Barro, R. (1979): "On the determination of the public debt," The Journal of Political Economy, 940-971.

BASU, S. (2009): "Sovereign debt and domestic economic fragility," Mimeo.

Bates, T., K. Kahle, And R. Stulz (2009): "Why do US firms hold so much more cash than they used to?" The Journal of Finance, 64, 1985-2021.

Baum, A., C. Checherita-Westphal, and P. Rother (2013): "Debt and growth: New evidence for the euro area," Journal of International Money and Finance, 32, 809-821.

Beck, T., A. Demirguc-Kunt, and R. Levine (2010): "Financial Institutions and Markets Across Countries and over Time: Data and Analysis," World Bank Economic Review, 24, 77-92.

Berkowitz, D., J. Moenius, And K. Pistor (2006): "Trade, law, and product complexity," the Review of Economics and Statistics, 88, 363-373.

Bertrand, M., E. Duflo, and S. Mullainathan (2004): "How Much Should We Trust Differences-in-Differences Estimates?" Quarterly Journal of Economics, 119, 249-275.

Beutler, T. And M. Grobéty (2011): "The Collateral Channel under Imperfect Debt Enforcement," Study Center Gerzensee Working Papers.

Bigelli, M. AND J. SÁnchez-Vidal (2011): "Cash holdings in private firms," Journal of Banking 83 Finance.

BIS (2009): "Guide to the international financial statistics," BIS Papers, 14.

Bolton, P. And O. Jeanne (2011): "Sovereign default risk and bank fragility in financially integrated economies," IMF Economic Review, 59, 162-194. 
Braun, M. (2005): "Financial contractibility and assets' hardness: industrial composition and growth," Havard University, mimeo.

Braun, M. And B. Larrain (2005): "Finance and the Business Cycle: International, InterIndustry Evidence," The Journal of Finance, 60, 1097-1128.

Brutti, F. (2011): "Sovereign defaults and liquidity crises," Journal of International Economics.

Burger, J. And F. WARnock (2003): "Diversification, Original Sin, and International Bond Portfolios," .

Caballero, R. and A. Krishnamurthy (2006): "Bubbles and capital flow volatility: Causes and risk management," Journal of monetary Economics, 53, 35-53.

Cameron, C., J. Gelbach, and D. Miller (2011): "Robust inference with multi-way clustering," Journal of Business and Economic statistics, 29, 238-249.

Campello, M., E. Giambona, J. R. Graham, and C. R. Harvey (2011): "Liquidity Management and Corporate Investment During a Financial Crisis," Review of Financial Studies, hhq131.

Cecchetti, S., M. Mohanty, And F. Zampoldi (2011): "The real effects of debt," BIS Working Papers, 352 .

Challe, E. And X. Ragot (2011): "Fiscal Policy in a Tractable Liquidity-Constrained Economy," The Economic Journal, 121, 273-317.

Chamon, M., E. Borensztein, O. Jeanne, P. Mauro, and J. Zettelmeyer (2005): "Sovereign Debt Structure for Crisis Prevention," IMF Occasional Papers.

Checherita-Westphal, C. And P. Rother (2012): "The impact of high government debt on economic growth and its channels: An empirical investigation for the euro area," European Economic Review.

Chen, J. And P. Imam (2013): "Causes of asset shortages in emerging markets," Review of Development Finance.

Chinn, M. And H. Iто (2006): "What matters for financial development? Capital controls, institutions, and interactions," Journal of Development Economics, 81, 163-192.

Claessens, S., D. Klingebiel, And S. Schmukler (2007): "Government bonds in domestic and foreign currency: the role of macroeconomic and institutional factors," Review of International Economics, 15, 370-413.

Cochrane, J. H. (2011): "Understanding policy in the great recession: Some unpleasant fiscal arithmetic," European Economic Review, 55, 2-30. 
Corsetti, G., K. Kuester, A. Meier, And G. J. Müller (2013): "Sovereign risk, fiscal policy, and macroeconomic stability," The Economic Journal, 123, F99-F132.

Dell'Erba, S., R. Hausmann, and U. Panizza (2013): "Debt levels, debt composition, and sovereign spreads in emerging and advanced economies," Oxford Review of Economic Policy, 29, $518-547$.

Diamond, P. (1965): "National debt in a neoclassical growth model," The American Economic Review, 55, 1126-1150.

Djankov, S., C. McLiesh, And A. Shleifer (2007): "Private credit in 129 countries," Journal of Financial Economics, 84, 299-329.

Dotsey, M. (1994): "Some unpleasant supply side arithmetic," Journal of Monetary Economics, $33,507-524$.

Duchin, R., O. Ozbas, And B. A. Sensoy (2010): "Costly external finance, corporate investment, and the subprime mortgage credit crisis," Journal of Financial Economics, 97, 418-435.

Easterly, W. (2001): "Growth Implosions and Debt Explosions: Do Growth Slowdowns Cause Public Debt Crises?" The BE Journal of Macroeconomics.

Eberhardt, M. and A. F. Presbitero (2015): "Public debt and growth: Heterogeneity and non-linearity," Journal of International Economics, 97, 45-58.

ÉGERT, B. (2015): "Public debt, economic growth and nonlinear effects: Myth or reality?" Journal of Macroeconomics, 43, 226-238.

Eichengreen, B., R. Hausmann, and U. Panizza (2007): "Currency Mismatches, Debt Intolerance, and the Original Sin: Why They Are Not the Same and Why It Matters," NBER Chapters, 121-170.

Falcetti, E. And A. Missale (2002): "Public debt indexation and denomination with an independent central bank," European Economic Review, 46, 1825-1850.

FARhi, E. And J. Tirole (2012): "Bubbly liquidity," The Review of Economic Studies, 79, 678706.

Fisman, R. AND I. Love (2007): "Financial dependence and growth revisited," Journal of the European Economic Association, 5, 470-479.

Fleming, M. (2000): "Financial Market Implications of the Federal Debt Paydown," Brookings Papers on Economic Activity, 2000, 221-251.

Forslund, K., L. Lima, And U. Panizza (2011): "The determinants of the composition of public debt in developing and emerging market countries," Review of Development Finance, 1, 207-222. 
Gennaioli, N., A. Martin, and S. Rossi (2014): "Sovereign default, domestic banks, and financial institutions," The Journal of Finance, 69, 819-866.

- (2016): "Banks, Government Bonds and Default: What do the Data Say?" mimeo.

Gorton, G., S. Lewellen, And A. Metrick (2012): "The safe-asset share," The American Economic Review, 102, 101-106.

Gorton, G. B. And G. Ordonez (2013): "The supply and demand for safe assets," Tech. rep., National Bureau of Economic Research.

Gwartney, J. D., J. C. Hall, And R. Lawson (2010): "Economic Freedom of the World: 2010 Annual Report," Vancouver: Frasier Institute.

HANSEn, B. E. (1999): "Threshold effects in non-dynamic panels: Estimation, testing, and inference," Journal of econometrics, 93, 345-368.

Hausmann, R. And U. Panizza (2003): "On the determinants of Original Sin: an empirical investigation," Journal of International Money and Finance, 22, 957-990.

(2011): "Redemption or Abstinence? Original Sin, Currency Mismatches and Counter Cyclical Policies in the New Millennium," Journal of Globalization and Development, 2, 4.

Heston, A., R. Summers, And B. Aten (2006): "Penn World Table Version 6.2," Center for International Comparisons of Production, Income and Prices at the University of Pennsylvania.

Holmström, B. And J. Tirole (1998): "Private and Public Supply of Liquidity," The Journal of Political Economy, 106, 1-40.

Hoshi, T., A. Kashyap, And D. Scharfstein (1991): "Corporate structure, liquidity, and investment: Evidence from Japanese industrial groups," The Quarterly Journal of Economics, $106,33-60$.

Ilyina, A. AND R. SAmaniego (2011): "Technology and financial development," Journal of Money, Credit and Banking, 43, 899-921.

Kaufmann, D., A. KraAy, and M. Mastruzzi (2009): "Governance matters VIII," Policy Research Working Paper, 4978.

Kim, C.-S., D. C. Mauer, And A. E. Sherman (1998): "The determinants of corporate liquidity: Theory and evidence," Journal of financial and quantitative analysis, 33, 335-359.

Kiyotaki, N. And J. Moore (2005): "Financial Deepening," Journal of the European Economic Association, 3, 701-713.

Kourtellos, A., T. Stengos, and C. M. Tan (2013): "The effect of public debt on growth in multiple regimes," Journal of Macroeconomics, 38, 35-43. 
Krishnamurthy, A. And A. Vissing-Jorgensen (2012): "The aggregate demand for treasury debt," Journal of Political Economy, 120, 233-267.

Kumar, M. And J. Woo (2010): "Public Debt and Growth," IMF Working Papers, 174, 1-47.

Kumhof, M. and E. Tanner (2005): "Government Debt: A Key Role in Financial Intermediation," IMF Working Papers.

Laeven, L. And F. VAlencia (2013): "Systemic banking crises database," IMF Economic Review, $61,225-270$.

Levchenko, A. (2007): "Institutional quality and international trade," Review of Economic Studies, 74, 791-819.

(2010): "International trade and institutional change," Michigan University, mimeo.

Levchenko, A., R. Rancière, and M. Thoenig (2009): "Growth and risk at the industry level: The real effects of financial liberalization," Journal of Development Economics, 89, 210-222.

Levine, R. And S. Zervos (1998): "Stock markets, banks, and economic growth," American economic review, 537-558.

Mehl, A. And J. Reynaud (2010): "Risky public domestic debt composition in emerging economies," Journal of International Money and Finance, 29, 1-18.

Moulton, B. (1986): "Random group effects and the precision of regression estimates," Journal of econometrics, 32, 385-397.

(1990): "An illustration of a pitfall in estimating the effects of aggregate variables on micro units," The Review of Economics and Statistics, 334-338.

Nicita, A. And M. Olarreaga (2007): "Trade, production, and protection database, 19762004," The World Bank Economic Review, 21, 165-171.

Opler, T., L. Pinkowitz, R. Stulz, and R. Williamson (1999): "The determinants and implications of corporate cash holdings," Journal of Financial Economics, 52, 46.

PANizZA, U. (2008): "Domestic and external public debt in developing countries," UNCTAD Discussion Papers.

Panizza, U. And A. Presbitero (2012): "Public debt and economic growth: is there a causal effect?" MoFiR Working Paper, 65.

Panizza, U. And A. F. Presbitero (2013): "Public debt and economic growth in advanced economies: A survey," Swiss Journal of Economics and Statistics, 149, 175-204. 
(2014): "Public debt and economic growth: is there a causal effect?" Journal of Macroeconomics, 41, 21-41.

Pescatori, A., D. Sandri, And J. Simon (2014): "Debt and Growth; Is There a Magic Threshold?" IMF Working Papers.

RADDATZ, C. (2006): "Liquidity needs and vulnerability to financial underdevelopment," Journal of Financial Economics, 80, 677-722.

Rajan, R. And L. Zingales (1998): "Financial Dependence and Growth," The American Economic Review, 88, 559-586.

Reinhart, C. And K. Rogoff (2004): "The modern history of exchange rate arrangements: A reinterpretation," Quarterly Journal of Economics, 119, 1-48.

- (2010a): "Growth in a Time of Debt," The American Economic Review, 100, 573-578.

- (2011a): "The Forgotten History of Domestic Debt," The Economic Journal, 121, 319-350.

(2011b): "From financial crash to debt crisis," The American Economic Review, 101, 16761706.

Reinhart, C., K. Rogoff, and M. Savastano (2003): "Debt Intolerance," Brookings Papers on Economic Activity, 2003, 1-62.

Reinhart, C. M., V. R. Reinhart, and K. S. Rogoff (2012): "Public debt overhangs: advanced-economy episodes since 1800," The Journal of Economic Perspectives, 26, 69-86.

Reinhart, C. M. And K. Rogoff (2010b): "Debt and growth revisited," VoxEU.org, 11 August.

Reinhart, V. And B. SACK (2000): "The Economic Consequences of Disappearing Government Debt," Brookings Papers on Economic Activity, 31, 163-220.

Saint-Paul, G. (1992): "Fiscal policy in an endogenous growth model," The Quarterly Journal of Economics, 107, 1243-1259.

- (2005): "Fiscal Policy and Economic Growth: The Role of Financial Intermediation," Review of International Economics, 13, 612-629.

Stock, J. And M. Yogo (2002): "Testing for weak instruments in linear IV regression," NBER Technical Working Paper, 284.

Woodford, M. (1990): "Public debt as private liquidity," The American Economic Review, 80, $382-388$. 


\section{Recent SNB Working Papers}

2017-13 Mathieu Grobéty:

Government Debt and Growth: The Role of Liquidity.

2017-12 Thomas Lustenberger and Enzo Rossi: Does Central Bank Transparency and Communication Affect Financial and Macroeconomic Forecasts?

2017-11 Andreas M. Fischer, Rafael Greminger and Christian Grisse: Portfolio rebalancing in times of stress.

2017-10 Christian Grisse and Silvio Schumacher: The response of long-term yields to negative interest rates: evidence from Switzerland.

2017-9 Petra Gerlach-Kristen, Richhild Moessner and Rina Rosenblatt-Wisch: Computing long-term market inflation expectations for countries without inflation expectation markets.

2017-8 Alain Galli: Which indicators matter? Analyzing the Swiss business cycle using a large-scale mixedfrequency dynamic factor model.

2017-7 Gregor Bäurle, Matthias Gubler and Diego R. Känzig International inflation spillovers - the role of different shocks.

2017-6 Lucas Marc Fuhrer: Liquidity in the Repo Market.

2017-5 Christian Grisse, Signe Krogstrup and Silvio Schumacher: Lower bound beliefs and long-term interest rates.

2017-4 Toni Beutler, Robert Bichsel, Adrian Bruhin and Jayson Danton: The Impact of Interest Rate Risk on Bank Lending.
2017-3 Raphael A. Auer, Andrei A. Levchenko and Philip Sauré: International Inflation Spillovers Through Input Linkages.

2017-2 Alain Galli, Christian Hepenstrick and Rolf Scheufele: Mixed-frequency models for tracking short-term economic developments in Switzerland.

2017-1 Matthias Gubler and Christoph Sax The Balassa-Samuelson Effect Reversed: New Evidence from OECD Countries.

2016-19 Jens H.E. Christensen and Signe Krogstrup: A Portfolio Model of Quantitative Easing.

2016-18 Jonas Meuli, Thomas Nellen and Thomas Nitschka: Securitisation, loan growth and bank funding: the Swiss experience since 1932.

2016-17 Rita Fleer, Barbara Rudolf and Mathias Zurlinden: Price change dispersion and time-varying pass-through to consumer prices.

2016-16 Gregor Bäurle, Daniel Kaufmann, Sylvia Kaufmann and Rodney W. Strachan: Changing dynamics at the zero lower bound.

2016-15 Adrian Jäggi, Martin Schlegel and Attilio Zanetti: Macroeconomic surprises, market environment and safe-haven currencies.

2016-14 Alain Galli: Sticky consumption and wealth effects in Switzerland.

2016-13 Gregor Bäurle and Rolf Scheufele: Credit cycles and real activity - the Swiss case. 
